Article

\title{
Hydrogen Production from Cyclic Chemical Looping Steam Methane Reforming over Yttrium Promoted Ni/SBA-16 Oxygen Carrier
}

\author{
Sanaz Daneshmand-Jahromi, Mohammad Reza Rahimpour *, Maryam Meshksar and Ali Hafizi \\ Department of Chemical Engineering, Shiraz University, Shiraz 71345, Iran; \\ Sanaz.daneshmand@yahoo.com (S.D.-J.); Meshksar.maryam@gmail.com (M.M.); hafizi@shirazu.ac.ir (A.H.) \\ * Correspondence: rahimpor@shirazu.ac.ir
}

Academic Editors: Ewa Kowalska, Marcin Janczarek and Agata Markowska-Szczupak

Received: 3 September 2017; Accepted: 22 September 2017; Published: 25 September 2017

\begin{abstract}
In this work, the modification of Ni/SBA-16 oxygen carrier $(\mathrm{OC})$ with yttrium promoter is investigated. The yttrium promoted Ni-based oxygen carrier was synthesized via co-impregnation method and applied in chemical looping steam methane reforming (CL-SMR) process, which is used for the production of clean energy carrier. The reaction temperature $\left(500-750{ }^{\circ} \mathrm{C}\right), \mathrm{Y}$ loading (2.5-7.4 wt. \%), steam/carbon molar ratio (1-5), Ni loading (10-30 wt. \%) and life time of OCs over 16 cycles at $650{ }^{\circ} \mathrm{C}$ were studied to investigate and optimize the structure of OC and process temperature with maximizing average methane conversion and hydrogen production yield. The synthesized OCs were characterized by multiples techniques. The results of X-ray powder diffraction (XRD) and energy dispersive X-ray spectroscopy (EDX) of reacted OCs showed that the presence of $\mathrm{Y}$ particles on the surface of OCs reduces the coke formation. The smaller NiO species were found for the yttrium promoted $\mathrm{OC}$ and therefore the distribution of Ni particles was improved. The reduction-oxidation (redox) results revealed that $25 \mathrm{Ni}-2.5 \mathrm{Y} / \mathrm{SBA}-16 \mathrm{OC}$ has the highest catalytic activity of about $99.83 \%$ average $\mathrm{CH}_{4}$ conversion and $85.34 \% \mathrm{H}_{2}$ production yield at reduction temperature of $650{ }^{\circ} \mathrm{C}$ with the steam to carbon molar ratio of 2 .
\end{abstract}

Keywords: chemical looping reforming of methane; yttrium promoted oxygen carrier; SBA-16; hydrogen production

\section{Introduction}

Fast depletion of conventional fossil fuel sources and increasing concerns over the global warming phenomenon due to the emissions of greenhouse gases especially carbon dioxide, initiated various researchers for the production of clean energies [1-6]. $\mathrm{H}_{2}$ has been widely identified as a favorable clean energy carrier because of its non-polluting nature and high specific energy density $(120.7 \mathrm{~kJ} / \mathrm{g})$ [7-9]. Recently, hydrogen can be produced by applying novel techniques with lower cost [9-11]. Reforming of fossil fuels, photo-catalytic water splitting, electrolysis and biomass gasification are hydrogen production technologies [9,12-15]. Steam methane reforming (SMR) is the most commonly used process in industry for the generation of $\mathrm{H}_{2}[16,17]$. However, SMR is energy intensive process and needs high level of capital investment that is not economically [18,19]. As an alternative method, chemical looping steam methane reforming (CL-SMR) process was proposed in order to overcome these drawbacks $[20,21]$. In this process the necessity of the gas separation is eliminated since the produced gas is not diluted with $\mathrm{N}_{2}$ [22,23]. A typical CL-SMR scheme consists of two interconnected reactors where there is no direct mixing of fuel and air as indicated in Figure 1. Methane is partially oxidized to syngas $\left(\mathrm{H}_{2}\right.$ and $\left.\mathrm{CO}\right)$ in the fuel reactor, while the metal oxide $\left(\mathrm{Me}_{x} \mathrm{O}_{y}\right)$ used as an oxygen 
carrier (OC) is reduced to $\mathrm{Me}_{x} \mathrm{O}_{y-1}$. The principle reactions that are involved in the fuel reactor are as follows:

$$
\begin{gathered}
\mathrm{CH}_{4}+\mathrm{Me}_{x} \mathrm{O}_{y} \rightarrow \mathrm{Me}_{x} \mathrm{O}_{y-s}+\mathrm{sCO}+2 \mathrm{H}_{2} \\
\mathrm{CO}+\mathrm{H}_{2} \mathrm{O} \leftrightarrow \mathrm{H}_{2}+\mathrm{CO}_{2}
\end{gathered}
$$

Then air is applied to re-oxidized the reduced OC at high temperature in the air reactor through the following reaction:

$$
2 \mathrm{Me}_{x} \mathrm{O}_{y-s}+\mathrm{sO}_{2} \rightarrow \mathrm{Me}_{x} \mathrm{O}_{y}
$$

Selection and development of an appropriate oxygen carrier is one of the most essential issues in CL-SMR process. The OC needs to possess adequate stability over multiple reduction-oxidation (redox) cycles. It also should have high methane conversion and selectivity to syngas, negligible coke deposition, high oxygen transfer rate and considerable strength to agglomeration, attrition, fragmentation and other chemical and mechanical degeneration types $[2,19,22,24]$.

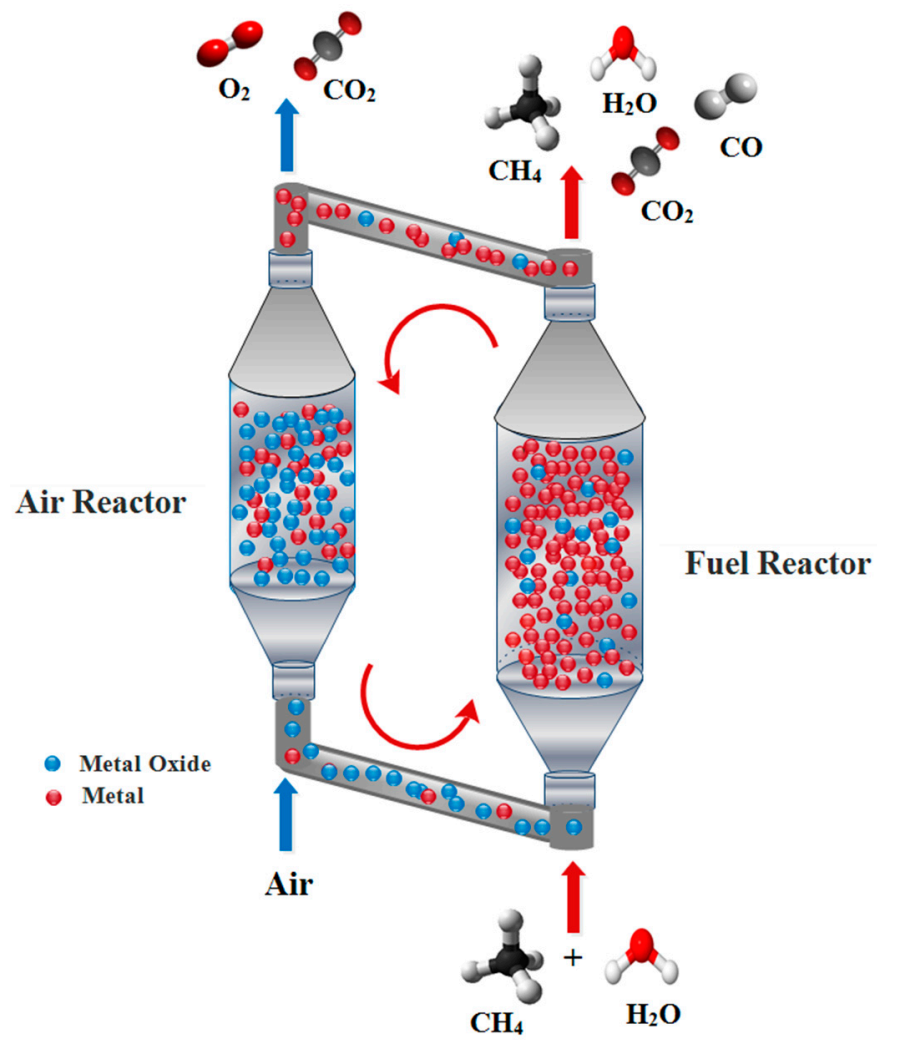

Figure 1. The schematic of CL-SMR reactor for synthesis gas production.

Among the various oxygen carriers, nickel-based OCs are the most promising and attractive candidate as active phase for CL-SMR process because of their high activity and selectivity toward $\mathrm{H}_{2}$ production. Also, they have wide availability and low cost compared to noble metal materials $[25,26]$. However, Ni-based systems generally suffer from severe deactivation caused by coke deposition and/or thermal sintering of the metallic phases due to their low tammann temperature (863 K) [27-29]. Therefore, some approaches have been applied in order to enhance the catalytic performance and durability of nickel-based materials in reforming reactions.

The first strategy is using a support with appropriate structural and textural properties that improves $\mathrm{Ni}$ dispersion over the carrier surface and inhibits the agglomeration of Ni nanoparticles [30,31]. Previous experiments have shown that the size of nickel particles have remarkable influence on its catalytic activity. Ni particles with sizes of several nanometers could supply more active Ni surface and could excellently 
reduce the graphite coke deposition [32-34]. Dispersing Ni particles on suitable supports such as porous silica can control the size of metallic Ni particles [35-39].

Silica-based mesoporous materials (e.g., SBA-n, MCM-48, MCM-41) have attracted much attention in many areas of material science and technology such as separations, adsorptions and catalysis [40,41]. They have shown good characteristics because of their high specific surface area, controllable pore size and pore volume. MCM-41 and SBA-15 have a uniform two-dimensional hexagonal ordered mesopore channel structure. However, the weak interaction between Ni nanoparticles and these kinds of supports leads nickel metallic particles to diffuse out of the mesoporous silica channels at elevated temperature [42]. Therefore, using three-dimensional cubic SBA-16 as a support of Ni-based material is an alternative way in order to enhance metal-support interaction. Santa Barbara Amorphous 16 (SBA-16) silica, has been known as an outstanding support for Ni-based materials due to its thick pore walls, excellent hydrothermal and thermal stability, high specific surface area and uniform pore size distribution [43].

Another popular strategy in order to avoid carbon formation and/or stabilizing Ni nanoparticles in the channels of two dimensional mesoporous silica is the utilization of promotional oxides such as $\mathrm{Ce}_{2} \mathrm{O}_{3}, \mathrm{La}_{2} \mathrm{O}_{3}, \mathrm{CaO}, \mathrm{MgO}$ and $\mathrm{Y}_{2} \mathrm{O}_{3}$ [44-48]. $\mathrm{Li}$ et al. [46] prepared Ce promoted $\mathrm{Ni} / \mathrm{SiO}_{2}$ catalyst using co-impregnation method and applied for producing syngas in the combined partial oxidation of methane with $\mathrm{CO}_{2}$ reforming. The results revealed that nickel-based catalyst has better performance in the presence of cerium promoter. Qian et al. [47] assessed Ni/SBA-15 catalysts with La promoter for dry reforming reaction. They have proved that highly dispersed La led to an increase of the $\mathrm{CO}_{2}$ conversion.

It was reported that the presence of $\mathrm{Y}_{2} \mathrm{O}_{3}$ particles reduces the metal particle size and prevents the coke formation due to high surface oxygen mobility. Shi et al. [49] have been investigated the performance of $\mathrm{Y}_{2} \mathrm{O}_{3}$ promoted $\mathrm{Pd} / \mathrm{Al}_{2} \mathrm{O}_{3}$ in dry $\left(\mathrm{CO}_{2}\right)$ reforming of $\mathrm{CH}_{4}$. They concluded that the addition of yttrium to $\mathrm{Pd} / \mathrm{Al}_{2} \mathrm{O}_{3}$ suppressed carbon formation and maintained Pd particle size below $10 \mathrm{~nm}$. Furthermore, the oxygen species mobility increased in the presence of $\mathrm{Y}_{2} \mathrm{O}_{3}$ promoter. $\mathrm{Li}$ et al. [50] applied sol gel method to synthesize 0-9\%Y-NiO/SBA-15 catalysts and tested them in dry reforming of $\mathrm{CH}_{4}$ process. The obtained results showed that the stronger interaction between support and metallic nickel particles is created as a result of $\mathrm{Y}_{2} \mathrm{O}_{3}$ promoter addition. Also, 9\%Y-NiO/SBA-15 showed low coke deposition and remarkable catalytic activity through dry methane reforming reaction.

Based on the above consideration, three-dimensional cubic SBA-16 material was applied as a support in order to synthesize Ni-based oxygen carriers in this research, and yttrium promoter was introduced to enhance the catalytic activity in CL-SMR process. Besides, some characteristics were employed for investigating the effect of yttrium addition on the catalytic and structural properties of $\mathrm{NiO}-\mathrm{Y}_{2} \mathrm{O}_{3} /$ SBA- 16 oxygen carrier.

\section{Results and Discussion}

\subsection{Sample Characterization}

\subsubsection{X-ray Powder Diffraction (XRD) Study}

Figure 2 displays the wide angle XRD diffraction patterns of fresh $25 \mathrm{Ni} / \mathrm{SBA}-16$ and $25 \mathrm{Ni}-2.5 \mathrm{Y} / \mathrm{SBA}-16$ oxygen carriers. Five well-resolved peaks at $2 \theta=37.3^{\circ}, 43.3^{\circ}, 62.9^{\circ}, 75.4^{\circ}$ and $79.4^{\circ}$, ascribable respectively to (111), (200), (220), (311) and (222) crystal planes of cubic nickel oxide (cod No. 01-078-0643), are observed for both samples. The crystallite sizes of the nickel particles were calculated using the Debye Scherrer's equation [51]. The results showed that the size of $\mathrm{NiO}$ crystallite of $25 \mathrm{Ni}-2.5 \mathrm{Y} / \mathrm{SBA}-16$ oxygen carrier is smaller than that of $25 \mathrm{Ni} / \mathrm{SBA}-16$ (Table 1 ). This suggests that the presence of $\mathrm{Y}_{2} \mathrm{O}_{3}$ led to the formation of $\mathrm{NiO}$ species with smaller size, which caused better dispersion of $\mathrm{NiO}$ particles on the surface of SBA-16 support. According to 01-083-0927 reference pattern code, $\mathrm{Y}_{2} \mathrm{O}_{3}$ is observed in $25 \mathrm{Ni}-2.5 \mathrm{Y} / \mathrm{SBA}-16$ sample at peaks of $2 \theta=20.5^{\circ}, 33.8^{\circ}, 48.5^{\circ}, 54.7^{\circ}$ and $85.9^{\circ}$. 


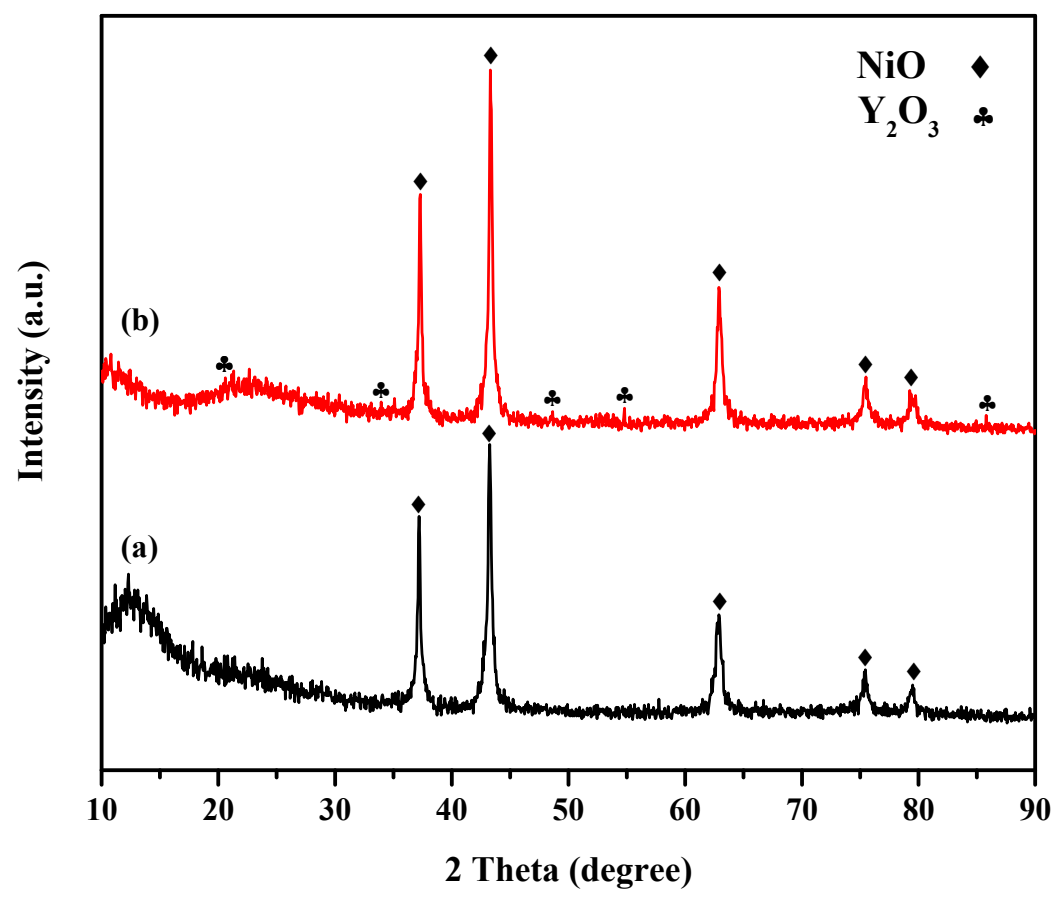

Figure 2. XRD patterns of (a) 25Ni/SBA-16 and (b) 25Ni-2.5Y/SBA-16.

Table 1. Structure properties of the prepared samples.

\begin{tabular}{ccccc}
\hline Samples & BET Surface Area $\left(\mathbf{m}^{2} / \mathbf{g}\right)$ & Pore Diameter $(\mathbf{n m})$ & Pore Volume $\left(\mathbf{c m}^{\mathbf{3}} / \mathbf{g}\right)$ & Crystal Size $^{\mathbf{a}}(\mathbf{n m})$ \\
\hline SBA-16 & 743.93 & 3.30 & 0.38 & - \\
25Ni/SBA-16 & 321.99 & 3.68 & 0.25 & 42.91 \\
25Ni-2.5Y/SBA-16 & 363.09 & 3.59 & 0.26 & 34.34 \\
\hline
\end{tabular}

${ }^{a}$ Crystal size of $\mathrm{NiO}$ calculated using the Debye Scherrer equation $(\mathrm{d}=0.89 \lambda / \beta \cos \theta)$.

\subsection{2. $\mathrm{N}_{2}$ Adsorption-Desorption Isotherms}

Nitrogen-physisorption analyses of pure SBA-16, 25Ni/SBA-16 and 25Ni-2.5Y/SBA-16 are shown in Figure 3a. As reported by IUPAC classification, all these prepared samples demonstrated type IV isotherm patterns with a $\mathrm{H} 2$ hysteresis loop at a range of about $\mathrm{P} / \mathrm{P}_{0}=0.4-0.7$, which represents the mesoporous hexagonal materials with cage like structure. This confirms that the mesoporous structure of SBA-16 is well preserved after impregnation of nickel active sites and yttrium promoters. However, the amount of adsorbed nitrogen is decreased upon impregnation of nickel and yttrium particles and therefore some porosity loss would be expected. The pore size distribution of pure SBA-16, 25Ni/SBA-16 and 25Ni-2.5Y/SBA-16 samples are obtained by BJH method and depicted in Figure $3 \mathrm{~b}$. All materials present sharp and narrow pore size distribution peaks, indicative of uniform mesopore structure. The mesopores of SBA- 16 and $25 \mathrm{Ni}-2.5 \mathrm{Y} / \mathrm{SBA}-16$ samples possess a pore size of about $3.5 \mathrm{~nm}$, while it is about $3.9 \mathrm{~nm}$ for $25 \mathrm{Ni} / \mathrm{SBA}-16$ oxygen carrier [52,53].

The major characteristics obtained by the nitrogen adsorption experiments are exhibited in Table 1. It can be clearly observed that after the addition of nickel active sites and yttrium promoter to the surface of SBA-16, the pore volume and specific surface area decreased significantly. These declines are due to the partial pore blocking caused by $\mathrm{NiO}$ and $\mathrm{Y}_{2} \mathrm{O}_{3}$ species posited on the surface of the SBA-16 support $[54,55]$. However, the pore volume and specific surface area of 25Ni-2.5Y/SBA-16 sample are higher than $25 \mathrm{Ni} / \mathrm{SBA}-16$ oxygen carrier, which showed that yttrium promoter developed the surface area of $25 \mathrm{Ni} / \mathrm{SBA}-16$ oxygen carrier and therefore improved the dispersion of Ni nanoparticles on the SBA-16 support [56,57]. Also, the addition of yttrium oxide to the oxygen carrier disperses fine $\mathrm{NiO}$ particles through the structure of SBA-16 support and inhibits the agglomeration of Ni active sites 
and pore blockage. Thus, the Brunauer-Emmett-Teller (BET) surface area of yttrium promoted oxygen carrier is higher than that of non-promoted $25 \mathrm{Ni} / \mathrm{SBA}-16$ oxygen carrier.
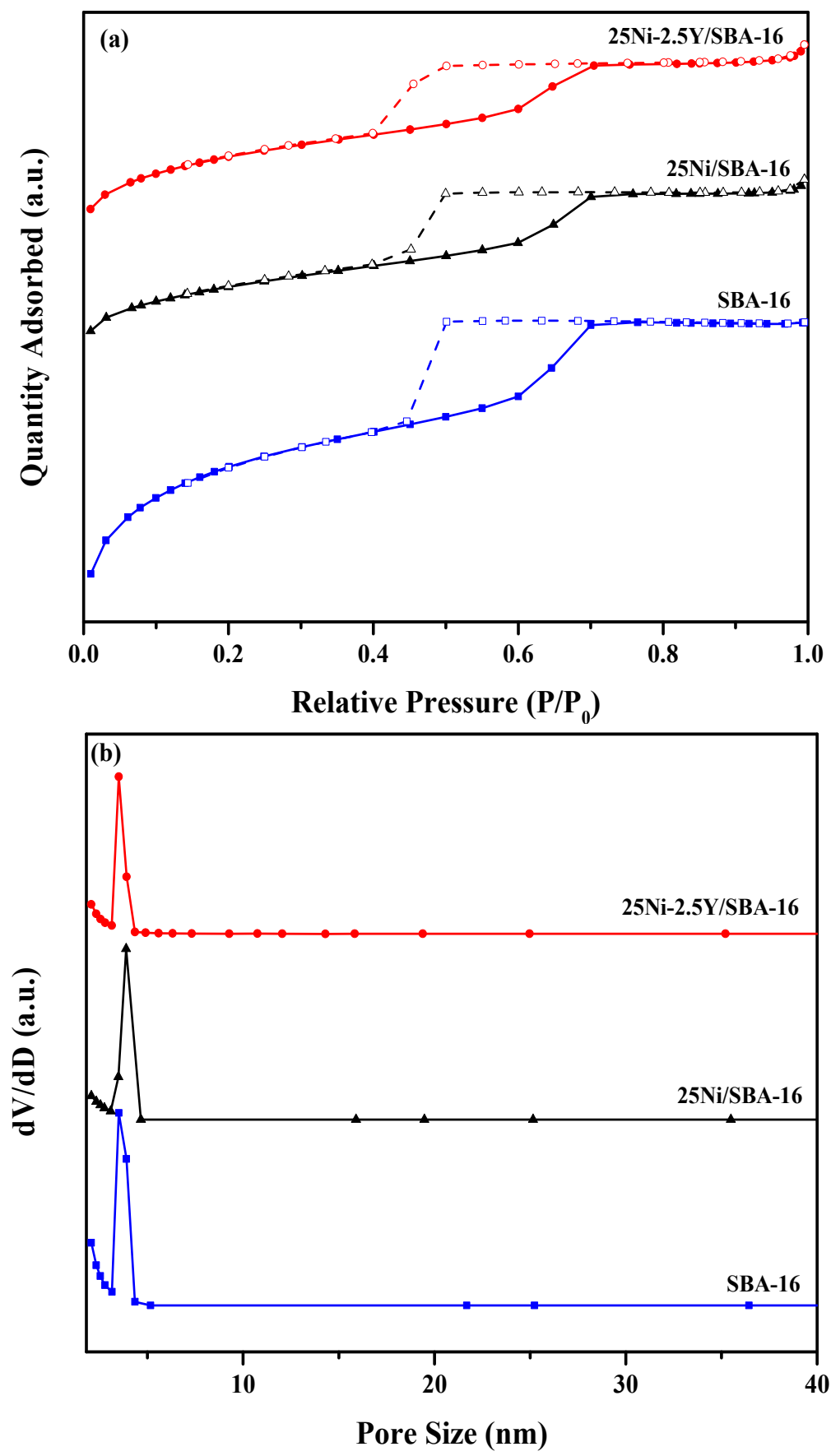

Figure 3. (a) $\mathrm{N}_{2}$ adsorption/desorption isotherms and (b) Pore size distribution of: SBA-16, 25Ni/SBA-16 and 25Ni-2.5Y/SBA-16.

\subsubsection{Field Emission Scanning Electron Microscopy (FESEM) Analysis}

The FESEM analysis was performed to evaluate the surface morphology of some samples. The FESEM micrographs of 25Ni-2.47Y/SBA-16 and 25Ni/SBA-16 oxygen carriers before CL-SMR process are dedicated in Figure 4. As exhibited in this figure, SBA-16 possesses 3-dimentional cubic and solid mesoporous structure. 


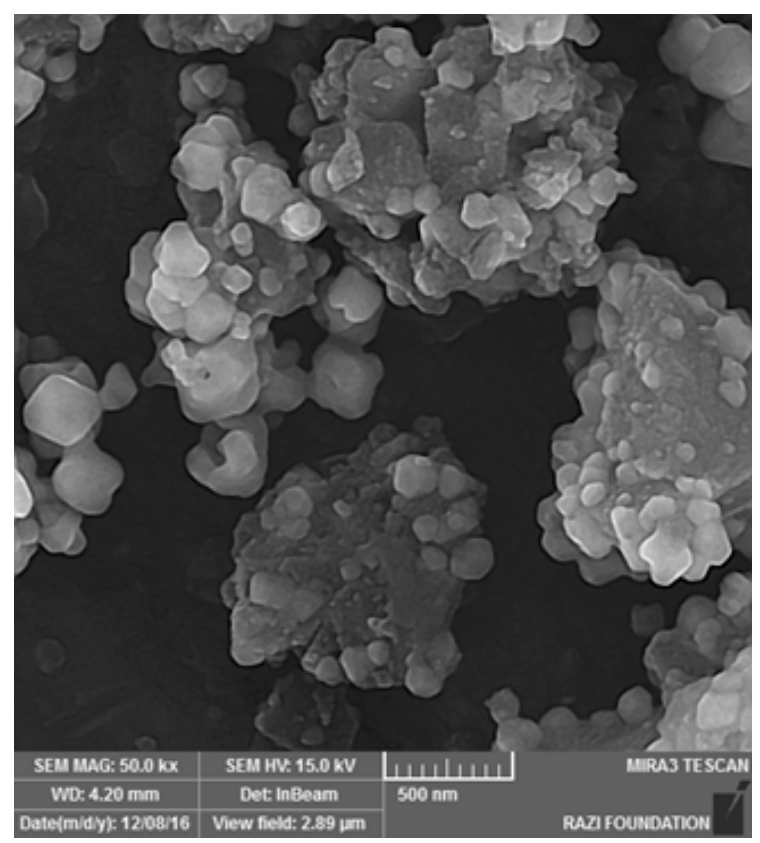

(a)

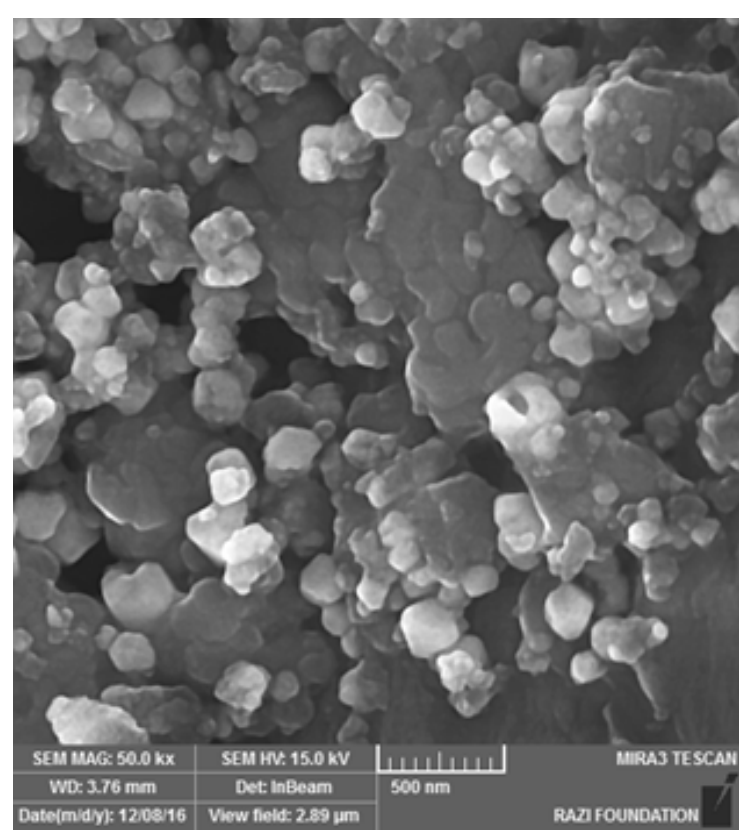

(b)

Figure 4. FESEM images of fresh (a) 25Ni/SBA-16 and (b) 25Ni-2.5Y/SBA-16 oxygen carriers.

\subsection{Effect of Yttrium Weight Percentage and Temperature on the Catalytic Activity}

To investigate the catalytic activity of different yttrium promoted Ni-based oxygen carriers, the samples with different $Y$ percentages are synthesized and tested in CL-SMR process. The yttrium weight percentage was changed from 0 to $7.4 \mathrm{wt} . \%$ in different reaction temperatures $\left(500-750{ }^{\circ} \mathrm{C}\right)$ with the steam to carbon molar ratio of 1.5. As depicted in Figure $5 \mathrm{a}$, the methane conversion increases with the rise of temperature, reflecting the endothermic nature of steam methane reforming process. Therefore, high temperature is favorable for increasing the methane conversion [58,59]. The yttrium free oxygen carrier (20Ni/SBA-16) showed the lowest methane conversion in all the temperature range studied. The performance of this oxygen carrier is greatly improved by the addition of yttrium to the support especially at lower reaction temperatures. As discussed previously in the result of XRD, the promotion of oxygen carrier with yttrium led to the better dispersion of nickel nanoparticles. Thus, the oxygen transfer rate is improved in these samples. For instance, by adding $2.5 \mathrm{wt}$. \% yttrium to the oxygen carrier, the average methane conversion is increased from $56.37 \%$ to $93.13 \%$ at the reduction temperature of $550^{\circ} \mathrm{C}$. It can be clearly observed that $20 \mathrm{Ni}-2.5 \mathrm{Y} / \mathrm{SBA}-16$ oxygen carrier had the highest catalytic activity and further increase of yttrium loading has negative effect on methane conversion. In addition, as indicated in Figure $5 \mathrm{~b}$, hydrogen production yield is increased by raising the reaction temperature. The average hydrogen yield of $20 \mathrm{Ni}-2.5 \mathrm{Y} / \mathrm{SBA}-16$ oxygen carrier is increased from $69.13 \%$ to $85.66 \%$ by increasing the temperature from 500 to $750{ }^{\circ} \mathrm{C}$. The highest average hydrogen yield is achieved by $20 \mathrm{Ni}-2.5 \mathrm{Y} / \mathrm{SBA}-16$ oxygen carrier. Consequently, $20 \mathrm{Ni}-2.5 \mathrm{Y} / \mathrm{SBA}-16$ has better proficiency and higher activity according to the results of methane conversion and average hydrogen yield.

In addition to high activity and hydrogen yield, it is important to reduce the coke deposition as the main effect of adding yttrium promoter. Thus, the energy dispersive $\mathrm{X}$-ray spectroscopy (EDX) analysis is carried out for the used samples with different yttrium contents.

The EDX analysis of used 20Ni-2.5Y/SBA-16, 20Ni-3.7Y/SBA-16 and 20Ni-7.4Y/SBA-16 oxygen carriers are presented in Figure $6 \mathrm{a}-\mathrm{c}$. As shown in this figure, carbon (C) element is detected in addition to Si, O, Ni and Y elements on the surface of all these used OCs. For 20Ni-7.4Y/SBA-16 OC, the coke deposited became less because of higher amount of $\mathrm{Y}_{2} \mathrm{O}_{3}$ particles on the surface of OC. As demonstrated in Figure $6 b, c$, the amount of $Y$ element for these two OCs is much lower than that 
the theoretical value, indicating the coverage of $\mathrm{Y}_{2} \mathrm{O}_{3}$ species by $\mathrm{NiO}$ nanoparticles on the surface of SBA-16. As a result, yttrium particles that are covered by $\mathrm{NiO}$ particles cannot inhibit the coke by releasing oxygen easily. Therefore, in spite of higher amount of yttrium in the synthesized mixture of 20Ni-3.7/SBA-16 OC compared with 20Ni-2.5Y/SBA-16, the coke deposited is approximately equal due to the similar amount of $\mathrm{Y}_{2} \mathrm{O}_{3}$ particles on the surface of the support. Although the carbon deposited on the 20Ni-2.5Y/SBA-16 OC was approximately higher than other OCs, the catalytic activity of this oxygen carrier was much better especially at lower temperature (Figure 5). Therefore, the yttrium weight percentage of 2.5 is the best yttrium loading on the surface of oxygen carrier.
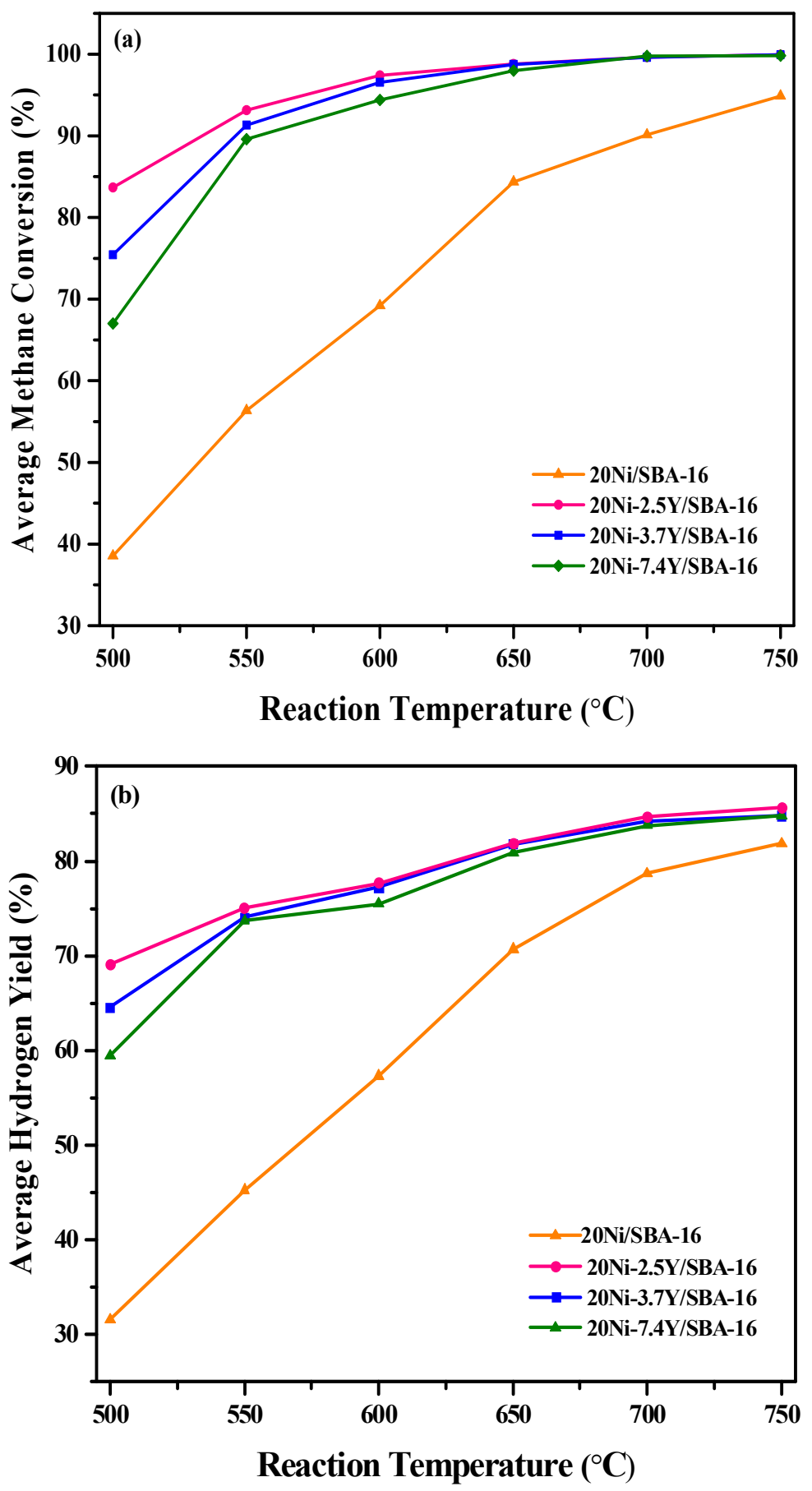

Figure 5. The effect of $\mathrm{Y}$ weight percentage and different reduction temperature on (a) Average methane conversion and (b) Average hydrogen yield of 20Ni-yY/SBA-16 oxygen carriers. 

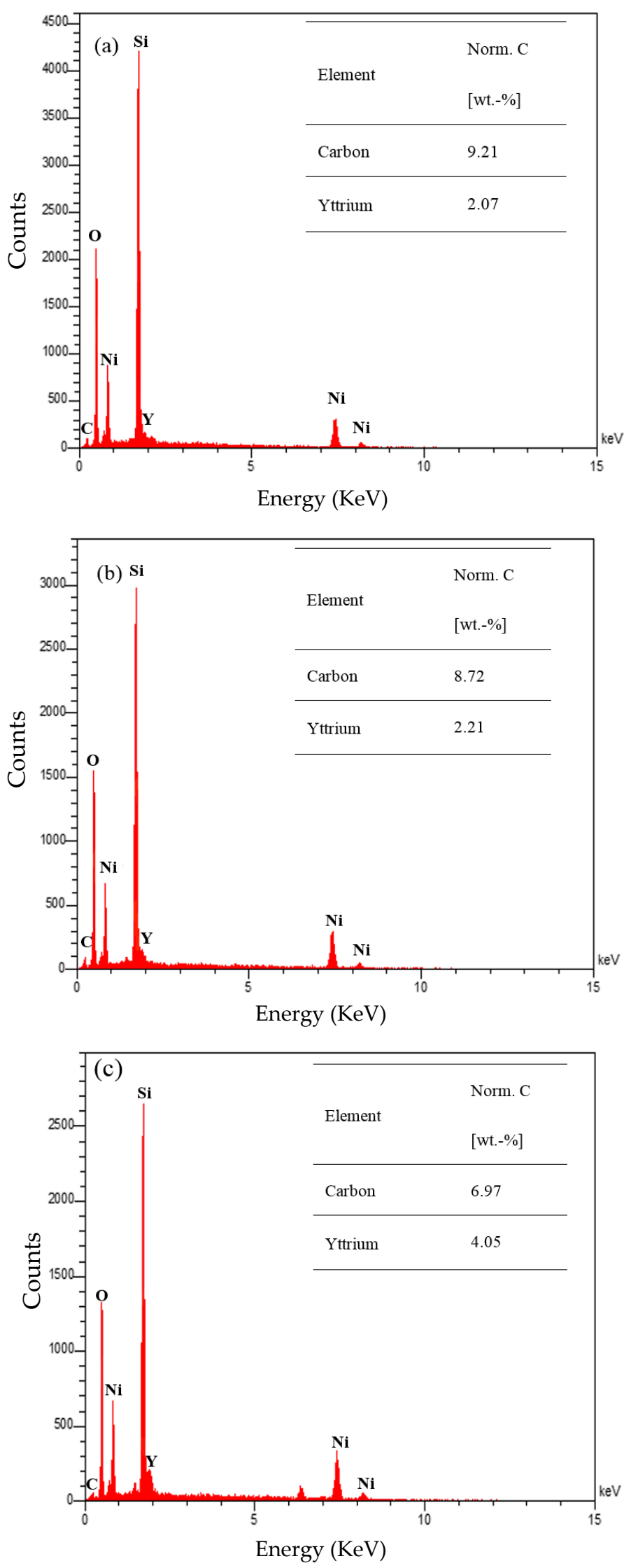

Figure 6. EDX of used (a) 20Ni-2.5Y/SBA-16; (b) 20Ni-3.7Y/SBA-16 and (c) 20Ni-7.4Y/SBA-16 oxygen carriers after 16 redox cycles at $650{ }^{\circ} \mathrm{C}$. 


\subsection{Life Time Investigation of Different Yttrium Weight Percentage}

To investigate the influence of different yttrium weight percentage on the life time of oxygen carrier, the synthesized samples were tested during 16 oxidation/reduction cycles at the temperature of $650{ }^{\circ} \mathrm{C}$ with the steam to methane molar ratio of 1.5 . Figure 7 demonstrates the average methane conversion and average hydrogen yield of 20Ni/SBA-16, 20Ni-2.5Y/SBA-16, 20Ni-3.7Y/SBA-16 and 20Ni-7.4Y/SBA-16 oxygen carriers. As shown in Figure 7, the average methane conversion and the average hydrogen yield of promoted oxygen carriers are higher than yttrium free sample during the cycles. It confirms the result obtained in the characterization section, which indicated the better distribution of nickel particles on the surface of support. In addition, it shows the higher oxygen mobility in the presence of yttrium promoter. The results revealed that the average $\mathrm{CH}_{4}$ conversion and average $\mathrm{H}_{2}$ yield of $20 \mathrm{Ni}-2.5 \mathrm{Y} / \mathrm{SBA}-16$ oxygen carrier are higher than other promoted oxygen carriers in most of successive redox cycles. It is noteworthy to say that the methane conversion of $99.21 \%$ and the average hydrogen yield of $84.87 \%$ were achieved using $20 \mathrm{Ni}-2.5 \mathrm{Y} / \mathrm{SBA}-16$ oxygen carrier. Therefore, according to Figure $7 \mathrm{a}, \mathrm{b}, 20 \mathrm{Ni}-2.5 \mathrm{Y} / \mathrm{SBA}-16$ oxygen carrier has highest stability compared with other oxygen carriers and also as demonstrated before, this oxygen carrier has higher activity and better proficiency. Therefore, the yttrium weight percentage of 2.5 is detected as the optimum yttrium loading.
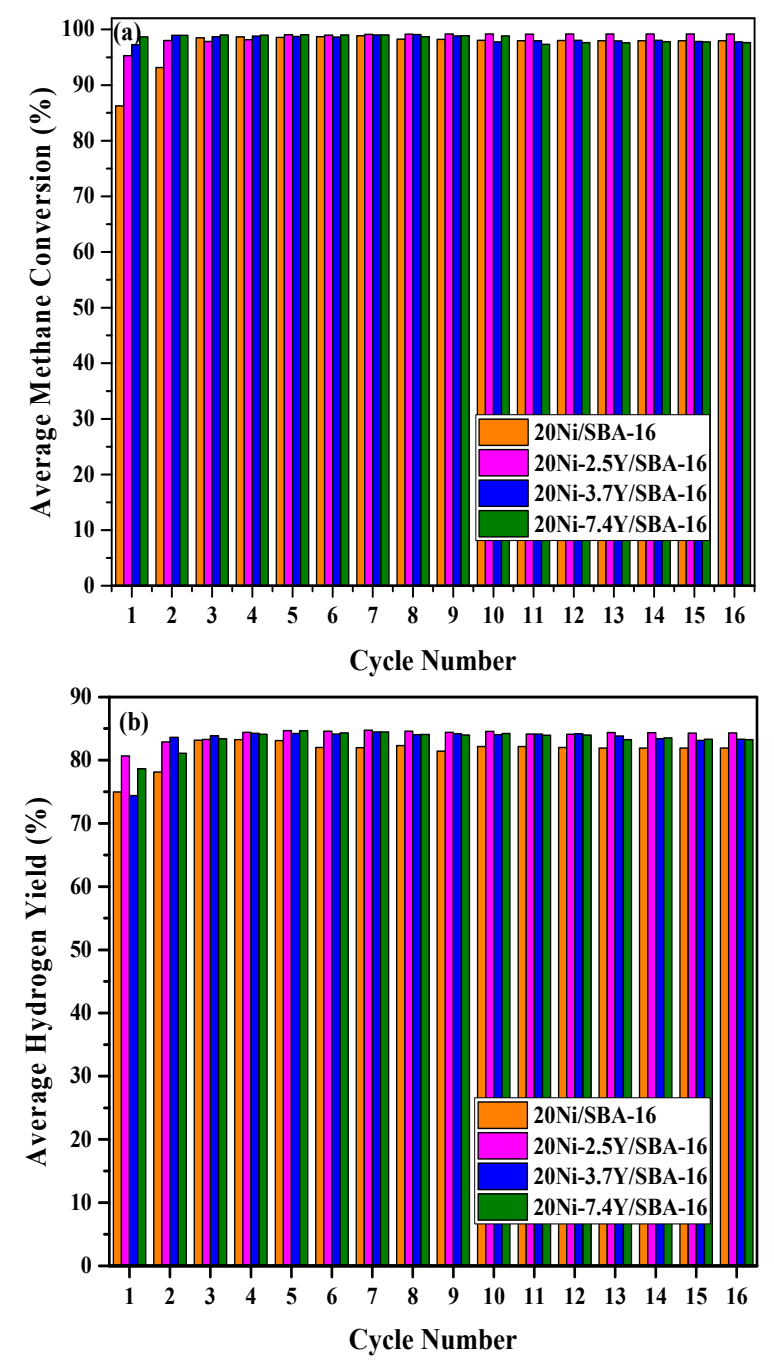

Figure 7. The Life time of $20 \mathrm{Ni}-\mathrm{yY} / \mathrm{SBA}-16$ oxygen carriers at $650^{\circ} \mathrm{C}$ : (a) Average methane conversion and (b) Average hydrogen yield. 


\subsection{Effect of Steam/Carbon Molar Ratio on the Catalytic Performance}

Figure 8 shows the average methane conversion and hydrogen yield at various steam to methane molar ratio $(1,1.5,2,3,4$ and 5$)$ at $650{ }^{\circ} \mathrm{C}$ using $20 \mathrm{Ni}-2.5 \mathrm{Y} / \mathrm{SBA}-16$ oxygen carrier. The S/C molar ratio is a significant parameter to determine reaction pathway of $\mathrm{CH}_{4}$ and distribution of product in the CL-SMR process. Using large excess steam is undesirable, since high operating expenditures are required [60,61]. As demonstrated in this figure, by increasing the $\mathrm{H}_{2} \mathrm{O} / \mathrm{CH}_{4}$ ratio to 2, the $\mathrm{CH}_{4}$ conversion and hydrogen yield were increased to $99.44 \%$ and $85.48 \%$, respectively and further increase of $\mathrm{H}_{2} \mathrm{O} / \mathrm{CH}_{4}$ ratio, caused slight negative effect on the activity of $\mathrm{OC}$ due to the pore blockage of oxygen carriers at higher steam to carbon molar ratios [62,63]. Therefore, the optimum average $\mathrm{CH}_{4}$ conversion and $\mathrm{H}_{2}$ yield were obtained at steam to carbon molar ratio of 2 .

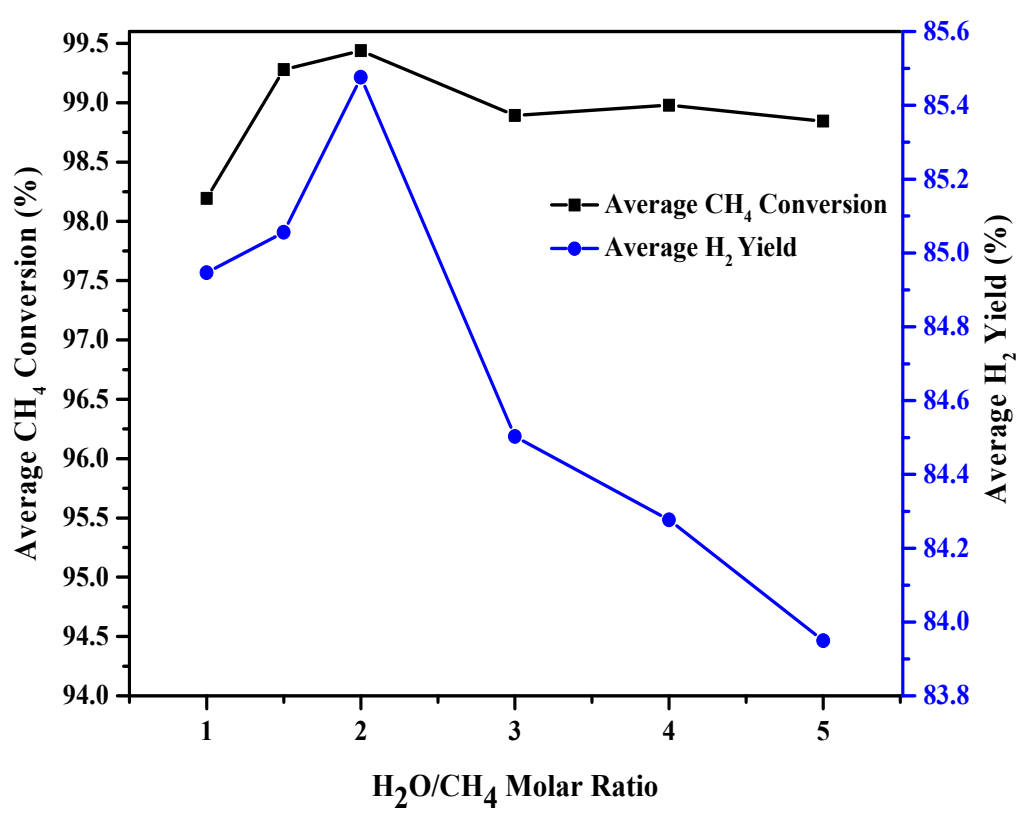

Figure 8. Average methane conversion and hydrogen yield of 20Ni-2.5Y/SBA-16 oxygen carrier at $650{ }^{\circ} \mathrm{C}$ for different $\mathrm{H}_{2} \mathrm{O} / \mathrm{CH}_{4}$ molar ratio.

\subsection{Effect of Ni Loading Percentage and Temperature on the Catalytic Activity}

In order to detect the optimum nickel weight percentage, $x$ Ni-2.5Y/SBA-16 $(x=10,15,20$, 25, $30 \mathrm{wt}$. \%) oxygen carriers were synthesized and investigated in CL-SMR process in various reduction temperatures $\left(500-750{ }^{\circ} \mathrm{C}\right)$ with steam to carbon molar ratio of 2 . The methane conversion during the cycle time and average hydrogen yield in different temperature are plotted in Figure 9. Because Ni loading percentage has great effect on the catalyst activity, its variation with time at different temperatures is plotted in Figure 9. As demonstrated in this figure, 25Ni-2.5Y/SBA-16 OC revealed the highest catalytic activity and average $\mathrm{H}_{2}$ yield in all temperature range. The average methane conversion of $25 \mathrm{Ni}-2.5 \mathrm{Y} / \mathrm{SBA}-16 \mathrm{OC}$ is about $91.09 \%$ at $500{ }^{\circ} \mathrm{C}$ (Figure $9 \mathrm{a}$ ) and increased to $100 \%$ at $700{ }^{\circ} \mathrm{C}$ (Figure $9 \mathrm{~b}$ ). In addition, the average hydrogen yield increased from about $78.05 \%$ to $85.33 \%$ with temperature rise from 500 to $650{ }^{\circ} \mathrm{C}$ using this OC. Actually, the performance of OCs with different nickel loadings displayed a maximum with raising the nickel content up to $25 \%$ and further increase of nickel loading percentage results in the reduction of $\mathrm{CH}_{4}$ conversion. The improvement of methane conversion with $\mathrm{Ni}$ loading percentage could be due to the more available lattice oxygen by increasing the $\mathrm{NiO}$ molecules. Afterwards the reduction in the activity is related to the agglomeration tendency of nickel particles at higher Ni weight percentage [48]. It can be concluded from Figure 9 that at higher reduction temperature the difference between catalytic activity and hydrogen production yield of $x$ Ni-2.5Y/SBA-16 ( $x=10,15,20,25,30 \mathrm{wt}$. \%) oxygen carriers are less significant. 


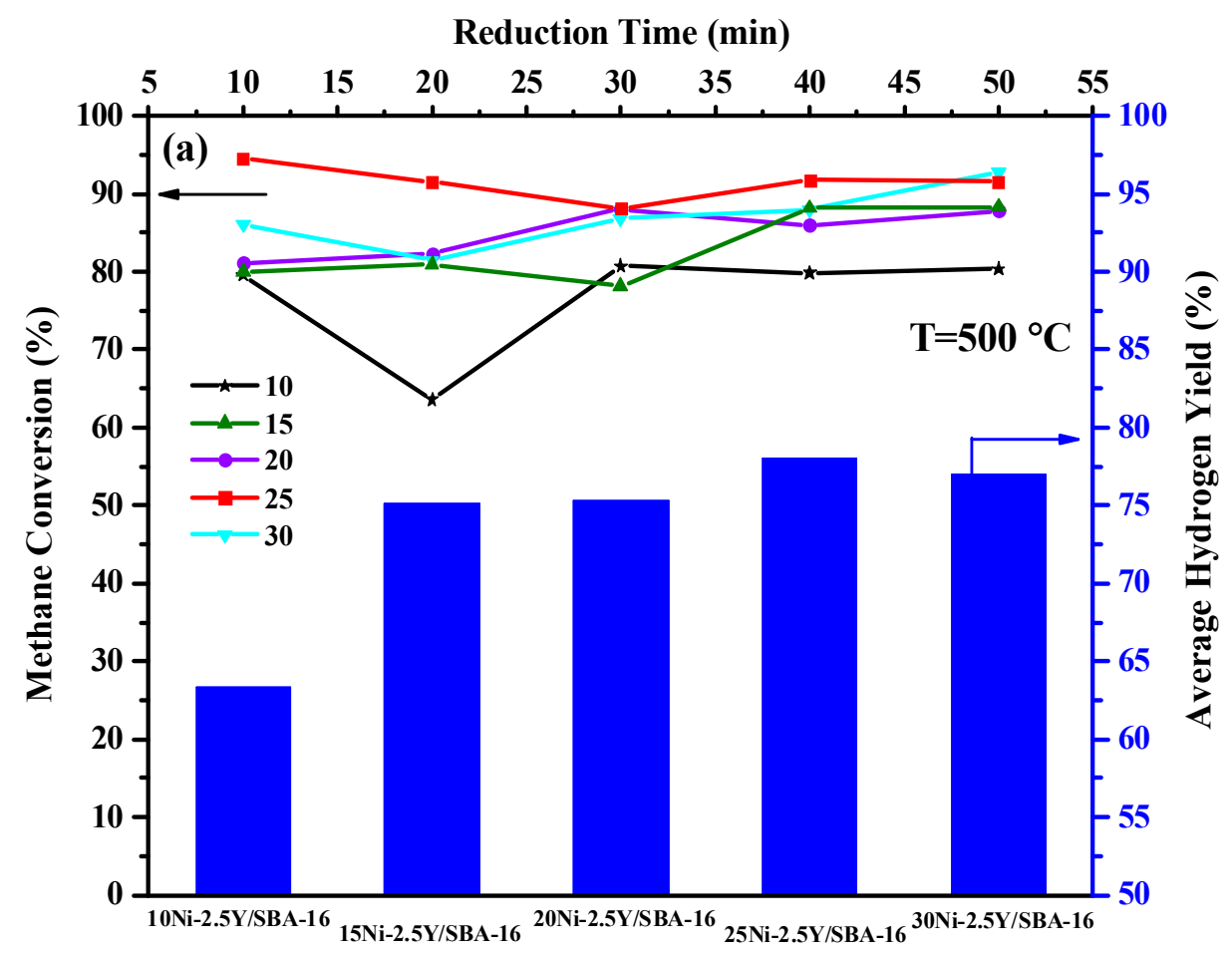

Type of Oxyge Carrier

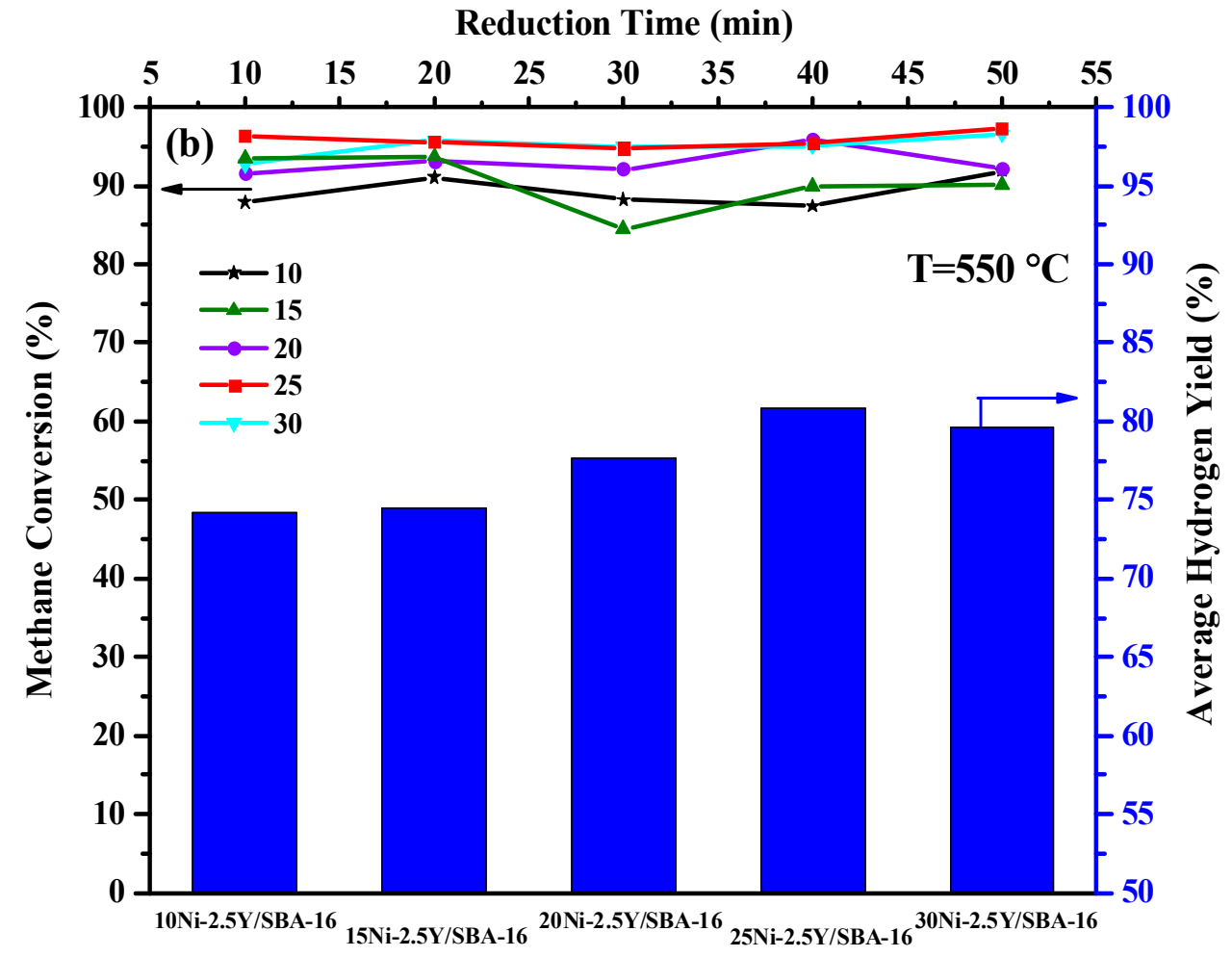

Type of Oxygen Carrier

Figure 9. Cont. 


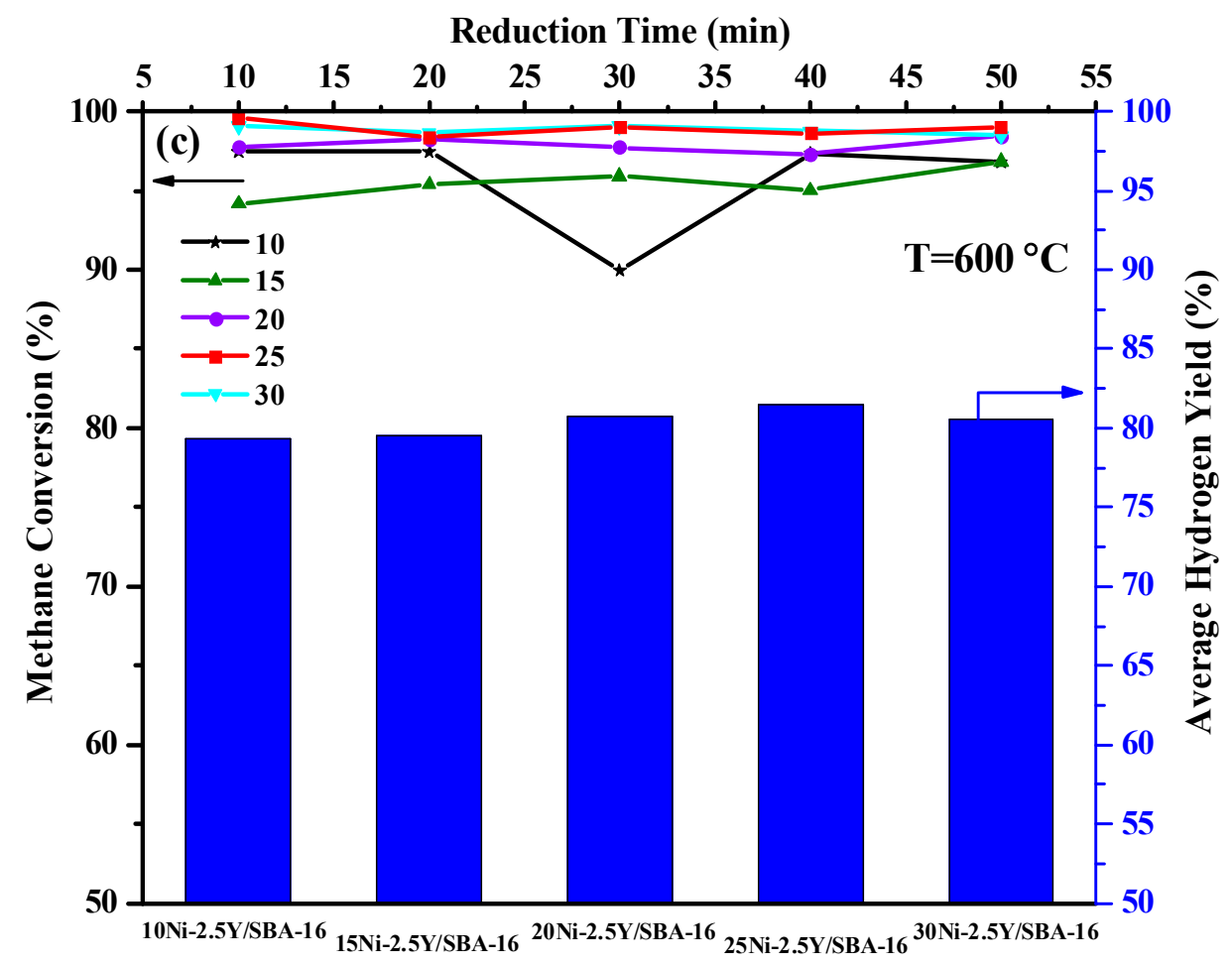

Type of Oxygen Carrier

Reduction Time (min)

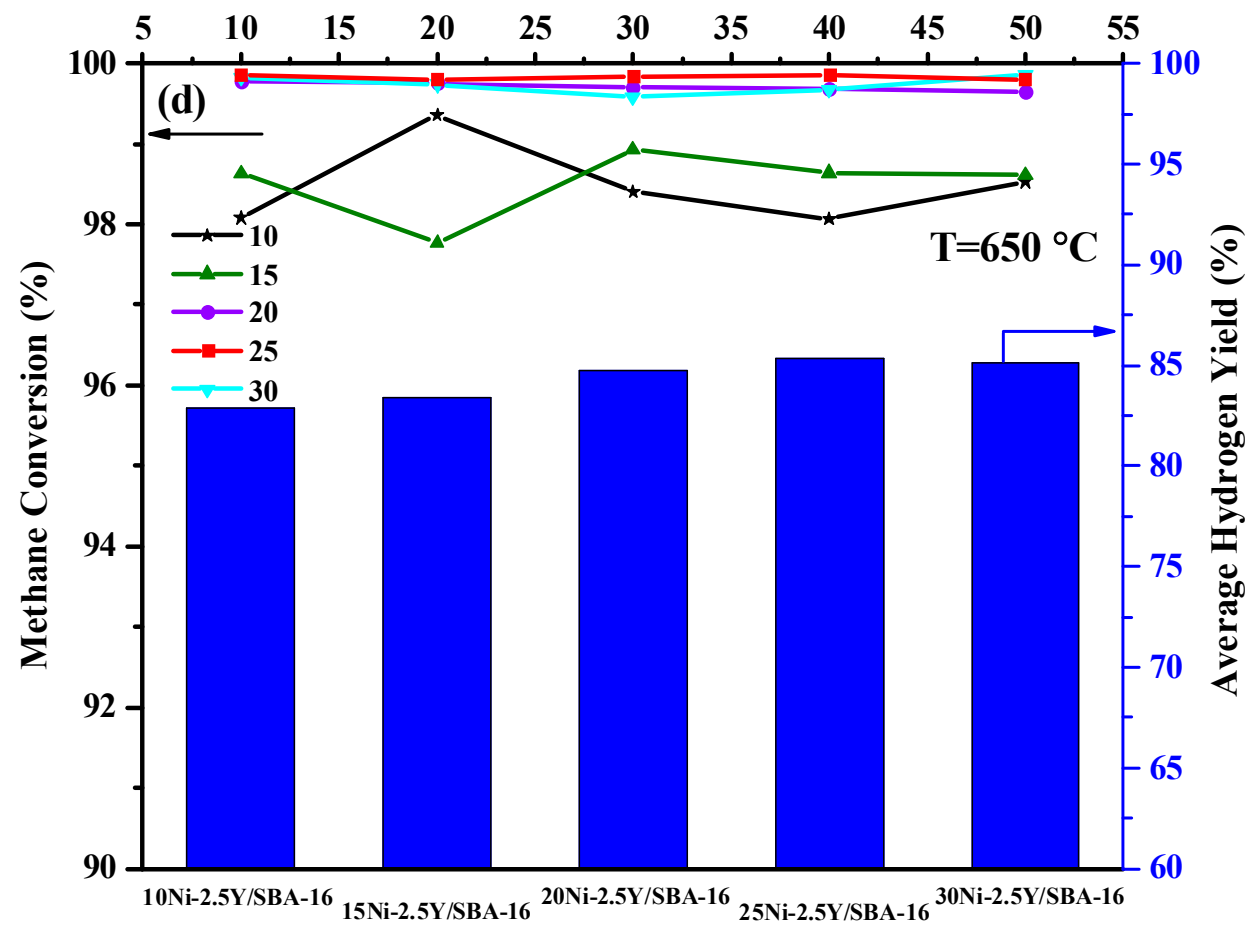

Type of Oxygen Carrier

Figure 9. Cont. 
Reduction Time (min)

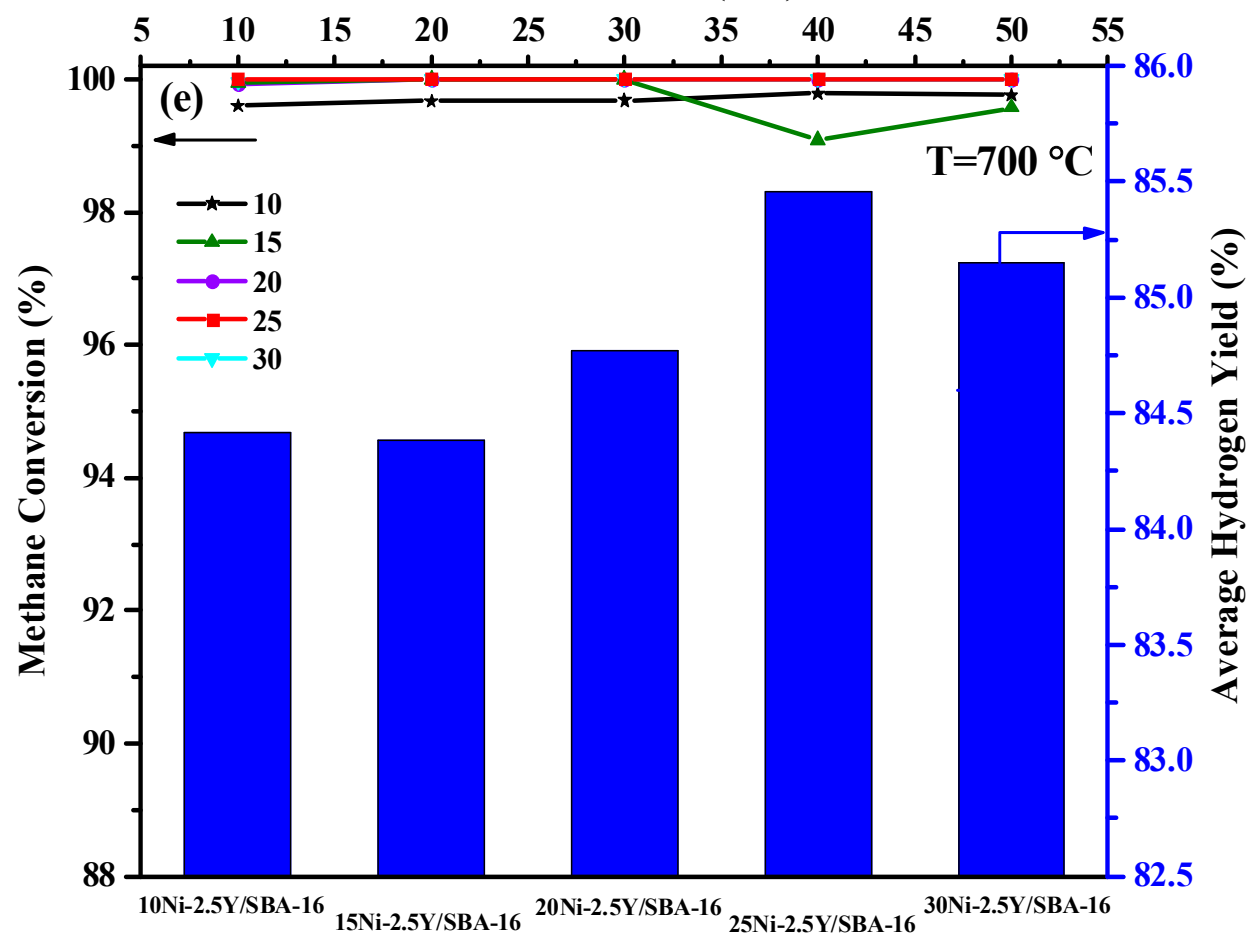

Type of Oxygen Carrier

Reduction Time (min)

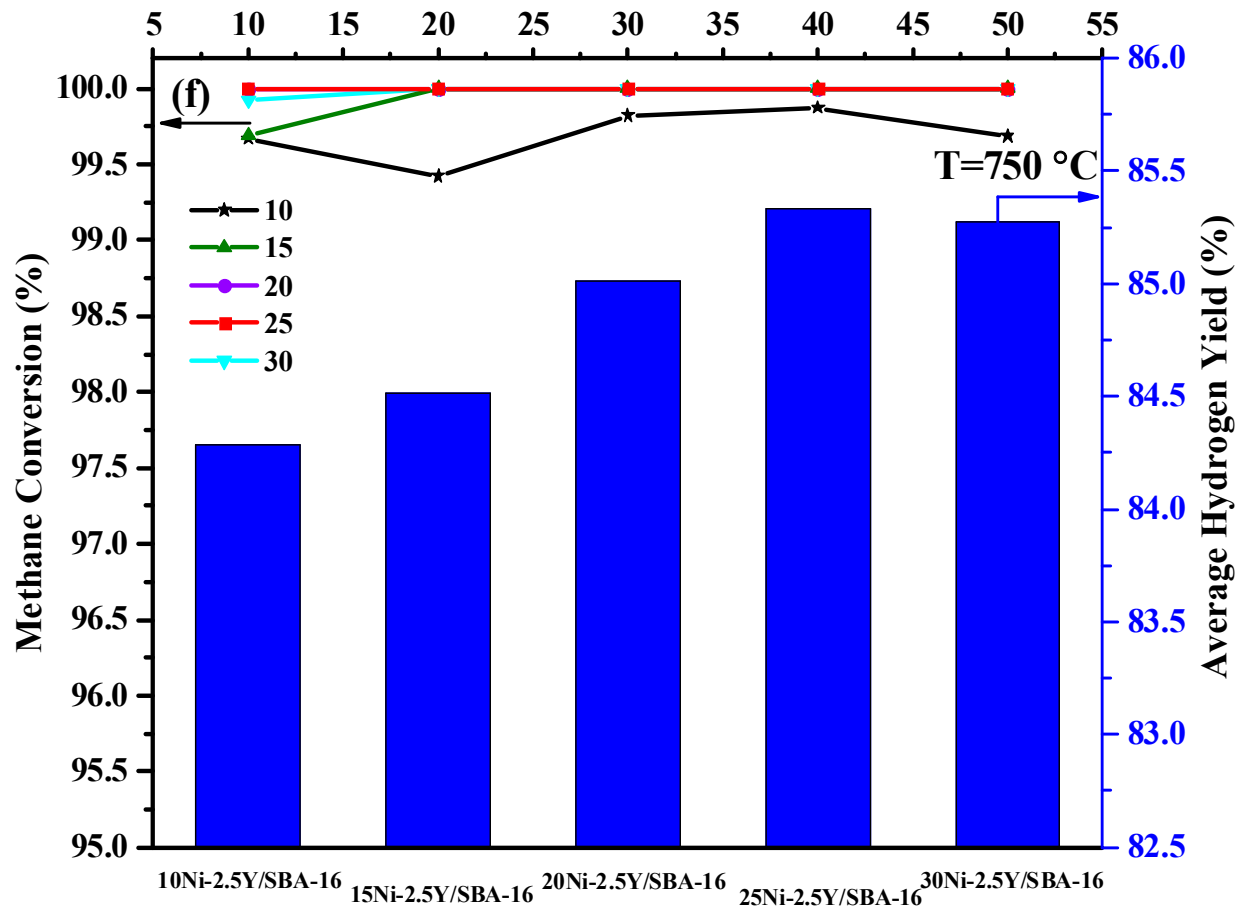

Type of Oxygen Carrier

Figure 9. The effect of $\mathrm{Ni}$ weight percentage on the methane conversion and average hydrogen yield of $\mathrm{xNi}-2.5 \mathrm{Y} / \mathrm{SBA}-16$ oxygen carriers at reduction temperature of (a) $500{ }^{\circ} \mathrm{C}$; (b) $550{ }^{\circ} \mathrm{C}$; (c) $600{ }^{\circ} \mathrm{C}$; (d) $650{ }^{\circ} \mathrm{C}$; (e) $700{ }^{\circ} \mathrm{C}$ and (f) $750{ }^{\circ} \mathrm{C}$. 


\subsection{Life Time of $25 \mathrm{Ni} / \mathrm{SBA}-16$ and $25 \mathrm{Ni}-2.5 \mathrm{Y} / \mathrm{SBA}-16$ Oxygen Carriers}

In order to investigate the effect of yttrium promoter on the durability of samples, $25 \mathrm{Ni} / \mathrm{SBA}-16$ and $25 \mathrm{Ni}-2.5 \mathrm{Y} / \mathrm{SBA}-16$ oxygen carriers were examined over 16 oxidation-reduction cycles at $650{ }^{\circ} \mathrm{C}$ with steam to carbon molar ration of 2. As represented in Figure 10, the average $\mathrm{CH}_{4}$ conversion and $\mathrm{H}_{2}$ production yield of promoted oxygen carrier is higher than that of yttrium free OC during cycles. A slight variation of methane conversion observed during the cycles and no sensible activity loss was detected over the 16 redox cycles for $25 \mathrm{Ni}-2.5 \mathrm{Y} / \mathrm{SBA}-16 \mathrm{OC}$. The highest $\mathrm{CH}_{4}$ conversion of about $99 \%$ and $\mathrm{H}_{2}$ yield of about $85 \%$ were achieved during the cycles at $650{ }^{\circ} \mathrm{C}$ using this OC. This can be due to better distribution of nickel nanoparticles on the surface of oxygen carrier in yttrium promoted OC according to XRD result. Therefore, oxygen transfer rate is improved in the presence of yttrium promoter. As shown in this figure, the average methane conversion and hydrogen production yield of non-promoted oxygen carrier increased during first six cycles. Then they decreased with slight slope in the next three cycles and after that remained constant. Coke formation on the surface of 25Ni/SBA-16 and/or agglomeration of $\mathrm{Ni}$ particles can be the result of this reduction in the catalytic activity [19].

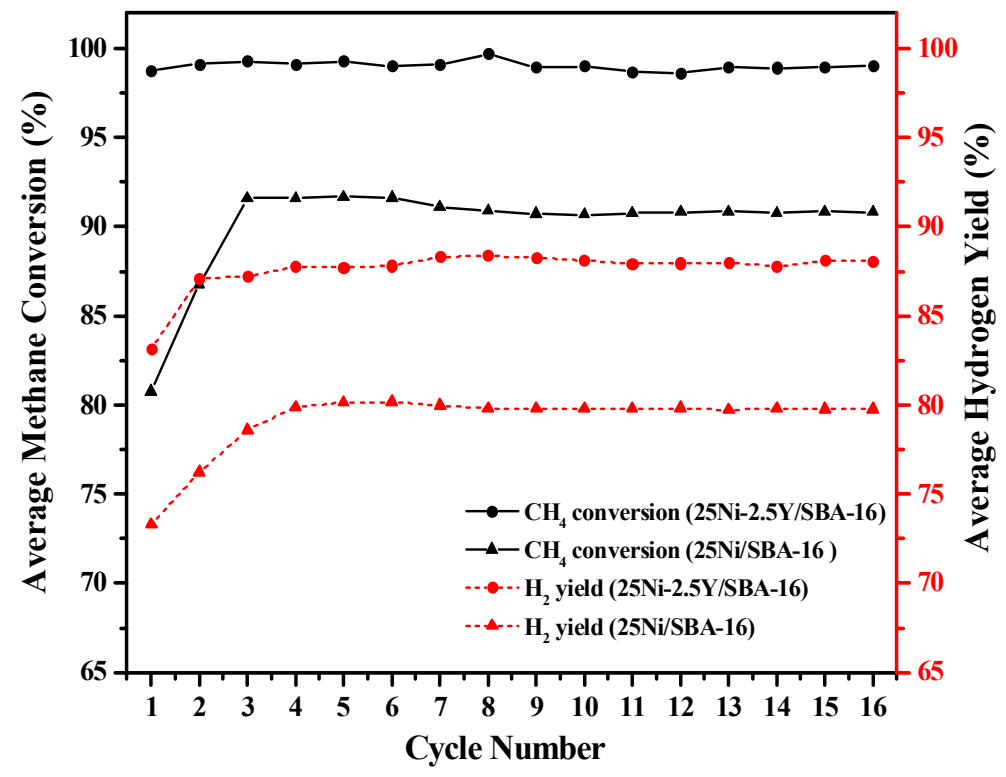

Figure 10. Life time of $25 \mathrm{Ni} / \mathrm{SBA}-16$ and $25 \mathrm{Ni}-2.5 \mathrm{Y} / \mathrm{SBA}-16$ oxygen carriers during 16 cycles at $650{ }^{\circ} \mathrm{C}$.

Table 2 shows the BET surface area, total pore volume and average pore size of $25 \mathrm{Ni}-2.5 \mathrm{Y} / \mathrm{SBA}-16$ and $25 \mathrm{Ni} / \mathrm{SBA}-16$ oxygen carriers after 16 redox cycles. Specific surface area and pore volume of both samples were decreased significantly due to sintering and blocking the pores during CL-SMR process at high temperature of $650{ }^{\circ} \mathrm{C}$. In addition, coke formation on the surface of oxygen carrier in reduction section can effectively decrease the specific surface area of samples [1]. It is noteworthy that the presence of yttrium on the surface of support leads to lower reduction in pore volume and specific surface area of $25 \mathrm{Ni}-2.5 \mathrm{Y} / \mathrm{SBA}-16$ compared to $25 \mathrm{Ni} / \mathrm{SBA}-16 \mathrm{OC}$.

Table 2. Structure characteristics of the spent $25 \mathrm{Ni} / \mathrm{SBA}-16$ and $25 \mathrm{Ni}-2.5 \mathrm{Y} / \mathrm{SBA}-16$ oxygen carriers after 16 redox cycles at $650{ }^{\circ} \mathrm{C}$.

\begin{tabular}{cccc}
\hline Oxygen Carrier & BET Surface Area $\left(\mathbf{m}^{2} / \mathbf{g}\right)$ & Pore Diameter $(\mathbf{n m})$ & Pore Volume $\left(\mathrm{cm}^{3} / \mathbf{g}\right)$ \\
\hline $25 \mathrm{Ni} / \mathrm{SBA}-16$ & 58.26 & 4.78 & 0.08 \\
$25 \mathrm{Ni}-2.5 \mathrm{Y} / \mathrm{SBA}-16$ & 144.04 & 3.99 & 0.15 \\
\hline
\end{tabular}


The XRD patterns of $25 \mathrm{Ni} / \mathrm{SBA}-16$ and $25 \mathrm{Ni}-2.5 \mathrm{Y} / \mathrm{SBA}-16$ oxygen carriers after 16 redox cycles are depicted in Figure 11. Both samples show the diffraction peaks of nickel at $2 \theta$ value of $44.5^{\circ}, 51.8^{\circ}$ and $76.4^{\circ}$ which respectively correspond to (111), (200) and (220) planes. This indicates that nickel oxide was reduced to metallic Ni during CL-SMR process. $\mathrm{Y}_{2} \mathrm{O}_{3}$ is observed in $25 \mathrm{Ni}-2.5 \mathrm{Y} / \mathrm{SBA}-16$ sample at peak of $2 \theta=79.7^{\circ}$. The carbon diffraction peak observed at $44.5^{\circ}$ for both samples was less pronounced in the case of $25 \mathrm{Ni}-2.5 \mathrm{Y} / \mathrm{SBA}-16$ oxygen carrier. It was reported that the presence of yttrium oxide enhanced the oxygen vacancies on the surface of support and promoted the mobility of oxygen so the carbon can be removed more easily over the yttrium promoted oxygen carrier [62]. Also, the peak at $2 \theta=43.8^{\circ}$ can be assigned to carbon for $25 \mathrm{Ni} / \mathrm{SBA}-16$ sample (cod. No. 00-050-1084). The formation of $\mathrm{NiCO}_{3}$ spinel in yttrium free oxygen carrier (25Ni/SBA-16) is evident at the diffraction peak of $43.4^{\circ}$ according to 00-012-0771 reference pattern code.
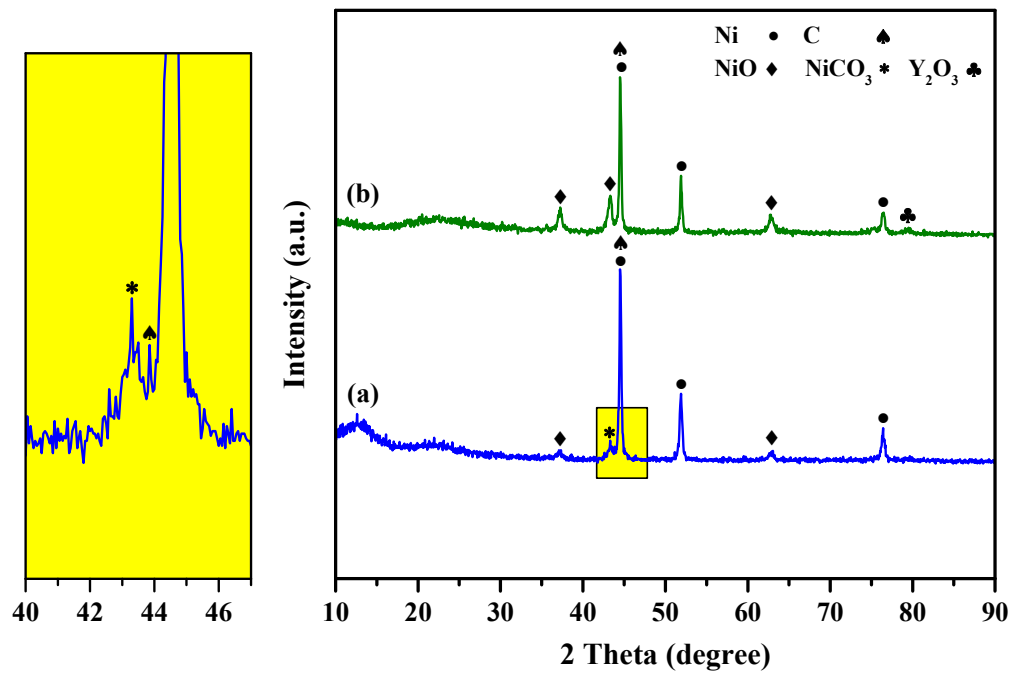

Figure 11. XRD patterns of (a) 25Ni/SBA-16 and (b) 25Ni-2.5Y/SBA-16 oxygen carriers.

Figure 12 shows the EDX analysis and FESEM images of spent $25 \mathrm{Ni} / \mathrm{SBA}-16$ and $25 \mathrm{Ni}-2.5 \mathrm{Y} / \mathrm{SBA}-16 \mathrm{OCs}$ in 16 redox cycles. As mentioned in this figure, $\mathrm{C}, \mathrm{O}, \mathrm{Ni}$, $\mathrm{Si}$ and $\mathrm{Y}$ atoms are presented in these OCs and the $\mathrm{C}$ element which represents the coke deposited on the SBA-16 support, was reduced from $10.61 \%$ to $4.93 \%$ on the $25 \mathrm{Ni}-2.5 \mathrm{Y} / \mathrm{SBA}-16$ OC. This can be due to the presence of $\mathrm{Y}_{2} \mathrm{O}_{3}$ species that have the ability to form oxycarbonate for oxidizing the surface carbon [64]. The FESEM images indicate the formation of $\mathrm{Ni}$ active sites with appropriate distribution on the surface of yttrium promoted OC which enhanced the catalytic activity.

The results presented in this paper demonstrated a better performance of Ni/SBA-16 OC with yttrium promoter compared with other oxygen carriers used previously in CL-SMR process. The average methane conversion of about $99.8 \%$ was achieved at $650{ }^{\circ} \mathrm{C}$ using $25 \mathrm{Ni}-2.5 \mathrm{Y} / \mathrm{SBA}-16$ oxygen carrier in the present work, while Belhadi et al. [65] obtained the methane conversion of about $72.0 \%$ and $88.0 \%$ at $700{ }^{\circ} \mathrm{C}$ using nickel based $\mathrm{ZrO}_{2}$ and $\mathrm{La}_{2} \mathrm{O}_{3}$ supports, respectively. As a comparison with Ni-based catalysts in SMR process, Wan et al. [66] achieved the methane conversion of $99.5 \%$ at $800{ }^{\circ} \mathrm{C}$ using $\mathrm{Ce}_{\mathrm{x}} \mathrm{Zr}_{1-\mathrm{x}} \mathrm{O}_{2}$ promoted Ni/SBA-15 catalyst. Furthermore, Rakass et al. [67] tested unsupported nickel powder catalyst for SMR and the methane conversion of $98.0 \%$ was achieved at $700{ }^{\circ} \mathrm{C}$. 

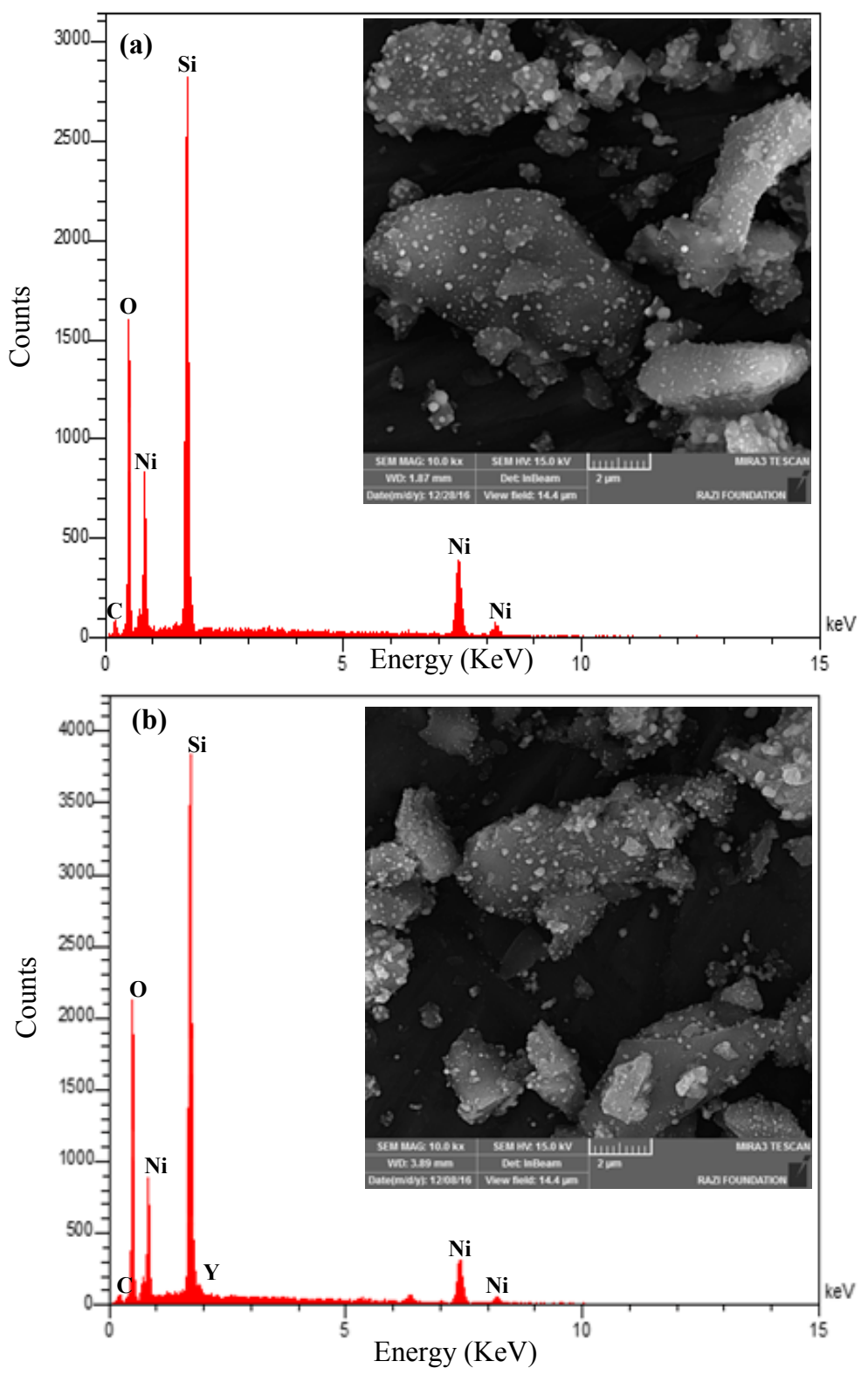

Figure 12. EDX and FESEM analysis of used (a) 25Ni/SBA-16 and (b) $25 \mathrm{Ni}-2.5 \mathrm{Y} / \mathrm{SBA}-16$ oxygen carriers.

\section{Experimental Methods}

\subsection{Oxygen Carrier Preparation}

SBA-16 support was synthesized using triblock copolymer Pluronic F127 $\left(\mathrm{EO}_{106} \mathrm{PO}_{70} \mathrm{EO}_{106}\right.$, $\mathrm{Mw}=12,600$, Aldrich, St. Louis, MO, USA) as the structure-directing agent and tetraethyl orthosilicate (TEOS, Merck, Kenilworth, NJ, USA) as the silica source by means of hydrothermal method. In a typical synthesis, $1.15 \mathrm{~g}$ F127 was dissolved in $\mathrm{HCl}$ (37 wt. \%) and de-ionized water under vigorous stirring at $40{ }^{\circ} \mathrm{C}$. Then, TEOS and butanol were added dropwise to the above solution. After stirring the mixture for $27 \mathrm{~h}$ at $40{ }^{\circ} \mathrm{C}$, it was transferred to the Teflon-lined autoclave and heated at $100{ }^{\circ} \mathrm{C}$ for two days. The solid product was recovered, washed with de-ionized water and ethanol for several times and dried at $100{ }^{\circ} \mathrm{C}$ for one day. Calcination was occurred at $550{ }^{\circ} \mathrm{C}$ for $6 \mathrm{~h}$ with a heating rate of $4^{\circ} \mathrm{C} / \mathrm{min}$ to remove the organic compounds of template and the formation of mesoporous structure of cubic SBA-16. It was used as a supporting material for Ni-Y/SBA-16 oxygen carrier. 
Final stage of preparation procedure was performed by co-impregnation of SBA-16 support with nickel nitrate and yttrium nitrate solutions. For this purpose, the separated solution of $\mathrm{Y}\left(\mathrm{NO}_{3}\right)_{3} \cdot 6 \mathrm{H}_{2} \mathrm{O}$ (Merck) and $\mathrm{Ni}\left(\mathrm{NO}_{3}\right)_{2} \cdot 6 \mathrm{H}_{2} \mathrm{O}$ (Merck) were added simultaneously to the support at $40{ }^{\circ} \mathrm{C}$. The solution was stirred for $5 \mathrm{~h}$ at $40^{\circ} \mathrm{C}$ in order to better diffusion of nickel and yttrium precursors into the pores of SBA-16. The impregnated OCs were dried at $100{ }^{\circ} \mathrm{C}$ for $15 \mathrm{~h}$ and then calcined at $650{ }^{\circ} \mathrm{C}$ for $3 \mathrm{~h}$. The solid product designated as $\mathrm{xNi}-\mathrm{y} \mathrm{Y} / \mathrm{SBA}-16$ where $\mathrm{x}=10,15,20,25 \& 30 \mathrm{wt}$. $\%$ and $\mathrm{y}=0,2.5,3.7 \& 7.4 \mathrm{wt}$. $\%$.

\subsection{Oxygen Carrier Characterization}

The synthesized OCs were characterized before and after reduction section in order to study their structural and catalytic properties via different techniques. The XRD patterns were collected on a powder Bruker D8 Advance Germany instrument equipped with $\mathrm{Cu} \mathrm{K} \alpha$ source at $40 \mathrm{kV}$ and $40 \mathrm{~mA}$ in the range of $2 \theta=10^{\circ}-90^{\circ}$ with a step size of $0.05^{\circ}$. In order to measure the specific surface area, BET method was applied by $\mathrm{N}_{2}$ adsorption/desorption isotherms using ASPA-2020 Instrument (Norcross, GA, USA). All the synthesized samples were degassed at $250{ }^{\circ} \mathrm{C}$ with nitrogen. The pore size distribution and the cumulative pore volume were achieved by the Barret-Joyner-Halenda (BJH) method from the desorption branches of $\mathrm{N}_{2}$ isotherms. FESEM images were recorded on a HITAGHI S-4160 system equipped with an EDX spectroscopy.

\subsection{Process Activity}

Gas-solid reactions consist of redox multi-cycles were done in a cylindrical stainless steel reactor which has an inner diameter of $16 \mathrm{~mm}$ with $1000 \mathrm{~mm}$ height. The fixed-bed reactor was inserted into a vertical electrical furnace and a k-type thermocouple posited at the center of the OC bed to monitor the temperature of the catalytic bed during the process. In each activity test, $1 \mathrm{~g}$ of freshly synthesized powdered OC (mesh size: 100-200 $\mu \mathrm{m}$ ) was packed on a thin porous layer in the middle of the reformer reactor. Deionized water was injected to the evaporator with syringe pump to generate steam. In the reduction step, the reactant gas streams $\left(\mathrm{CH}_{4}\right.$ as reactant and $\mathrm{Ar}$ as carrier gas) were controlled through two distinct mass flow controllers (MFCs) and mixed with steam before the reactor entrance. The reduction section was carried out by changing temperature from 500 to $750{ }^{\circ} \mathrm{C}$ at atmospheric pressure for $50 \mathrm{~min}$. The feed mixture entered the bed at the reaction temperature and reacted with lattice oxygen of solid OCs. In the oxidation step, the stream of $20 \mathrm{vol} \% \mathrm{O}_{2}$ diluted in $\mathrm{Ar}$ with the total flow rate of $124 \mathrm{~mL} \mathrm{~min}^{-1}$ was fed into the reactor to reoxidize the oxygen carriers and removing the deposited carbon. The oxidation and reduction periods were dissociated by purging Ar for $3 \mathrm{~min}$. The products of the reactor were passed through a condenser in order to liquefy the steam from gaseous product. Finally, the product and unreacted gas streams were analyzed using an online Bruker 450 gas chromatograph (GC) system every ten minutes. This means that the outlet gas was analyzed five times for each temperature. It is noteworthy to say that the first sample injection was carried out $10 \mathrm{~min}$ after the beginning of the reaction. Thus, the short transient state period is passed and it could be in the steady state section. Figure 13 indicates the schematic of the designated reactor applied for investigating the performance of oxygen carriers. Methane conversion $\left(\mathrm{X}_{\mathrm{CH}_{4}}\right)$ and hydrogen production yield $\left(\mathrm{y}_{\mathrm{H}_{2}}\right)$ were calculated as follows:

$$
\begin{gathered}
\mathrm{X}_{\mathrm{CH}_{4}}=\frac{\left(\text { moles of } \mathrm{CH}_{4}\right)_{\text {in }}-\left(\text { moles of } \mathrm{CH}_{4}\right)_{\text {out }}}{\left(\text { moles of } \mathrm{CH}_{4}\right)_{\text {in }}} \times 100 \\
\mathrm{y}_{\mathrm{H}_{2}}=\frac{\left(\text { moles of } \mathrm{H}_{2}\right)_{\text {out }}}{2 *\left(\text { moles of } \mathrm{CH}_{4}\right)_{\text {in }}} \times 100
\end{gathered}
$$




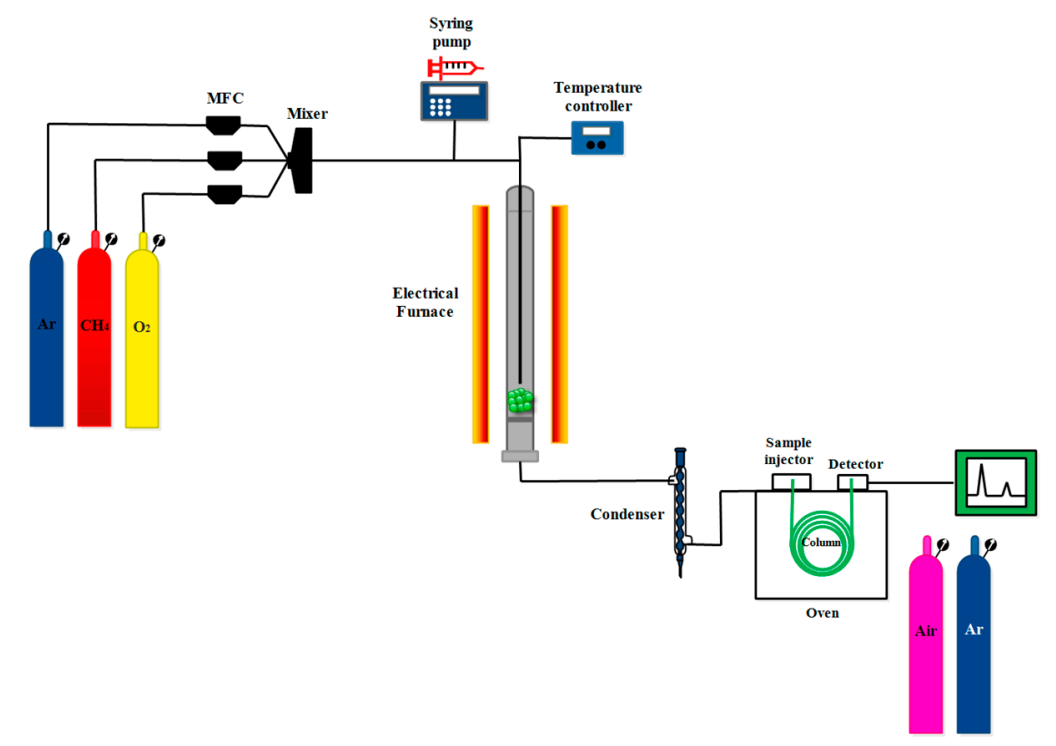

Figure 13. Reactor system for CL-SMR.

\section{Conclusions}

Structural characterization and catalytic activity of yttrium promoted Ni-based oxygen carriers were examined in chemical looping steam methane reforming process to produce synthesis gas. The oxygen carriers were synthesized via co-impregnation method and the effect of Ni loading (10-30 wt. \%), Y weight percentage $\left(0-7.4\right.$ wt. \%), reaction temperature $\left(500-750{ }^{\circ} \mathrm{C}\right)$, steam to methane molar ratio (1-5) and life time of oxygen carriers over 16 redox cycles were successfully investigated. The reduction temperature revealed significant effect on $\mathrm{CH}_{4}$ conversion and $\mathrm{H}_{2}$ production yield of all prepared samples. The reaction temperature of $650{ }^{\circ} \mathrm{C}$ and $\mathrm{H}_{2} \mathrm{O} / \mathrm{CH}_{4}$ molar ratio of 2 were the optimum reduction condition using $25 \mathrm{Ni}-60 \mathrm{Y} / \mathrm{SBA}-16$ oxygen carrier to achieve $99.83 \%$ methane conversion and $85.34 \%$ hydrogen yield. The characterization results showed that better dispersion of $\mathrm{Ni}$ active sites, higher specific surface area and lower coke deposited were achieved using yttrium as a promoter on the surface of oxygen carrier. Thus, the catalytic activity and long-term stability of OCs were improved after the addition of yttrium promoter on SBA-16 support.

Author Contributions: S.D.-J., M.M. and A.H. conceived and designed the experiments; S.D.-J. and M.M. performed the experiments; S.D.-J. and M.M. performed catalyst synthesis; S.D.-J., M.M. and A.H. analyzed the data; M.R.R. contributed reagents/materials/analysis tools; M.R.R. participated in the analysis and interpretation of characterization results; and S.D.-J. and M.M. wrote the paper.

Conflicts of Interest: The authors declare no conflict of interest.

\section{References}

1. Hafizi, A.; Rahimpour, M.R.; Hassanajili, S. Calcium promoted $\mathrm{Fe} / \mathrm{Al}_{2} \mathrm{O}_{3}$ oxygen carrier for hydrogen production via cyclic chemical looping steam methane reforming process. Int. J. Hydrogen Energy 2015, 40, 16159-16168. [CrossRef]

2. Hafizi, A.; Rahimpour, M.R.; Hassanajili, S. Hydrogen production by chemical looping steam reforming of methane over Mg promoted iron oxygen carrier: Optimization using design of experiments. J. Taiwan Inst. Chem. Eng. 2016, 62, 140-1409. [CrossRef]

3. Karimi, E.; Forutan, H.; Saidi, M.; Rahimpour, M.R.; Shariati, A. Experimental study of chemical-looping reforming in a fixed-bed reactor: Performance investigation of different oxygen carriers on $\mathrm{Al}_{2} \mathrm{O}_{3}$ and $\mathrm{TiO}_{2}$ support. Energy Fuels 2014, 28, 2811-2820. [CrossRef]

4. Frusteri, F.; Freni, S.; Spadaro, L.; Chiodo, V.; Bonura, G.; Donato, S.; Cavallaro, S. H2 production for MC fuel cell by steam reforming of ethanol over $\mathrm{MgO}$ supported $\mathrm{Pd}, \mathrm{Rh}, \mathrm{Ni}$ and Co catalysts. Catal. Commun. 2004, 5, 611-615. [CrossRef] 
5. Wang, Y.; Chen, M.; Liang, T.; Yang, Z.; Yang, J.; Liu, S. Hydrogen generation from catalytic steam reforming of acetic acid by Ni/attapulgite catalysts. Catalysts 2016, 6, 172. [CrossRef]

6. Du, Y.-L.; Wu, X.; Cheng, Q.; Huang, Y.-L.; Huang, W. Development of Ni-based catalysts derived from hydrotalcite-like compounds precursors for synthesis gas production via methane or ethanol reforming. Catalysts 2017, 7, 70. [CrossRef]

7. Midilli, A.; Ay, M.; Dincer, I.; Rosen, M. On hydrogen and hydrogen energy strategies: I: Current status and needs. Renew. Sustain. Energy Rev. 2005, 9, 255-271. [CrossRef]

8. Momirlan, M.; Veziroglu, T.N. The properties of hydrogen as fuel tomorrow in sustainable energy system for a cleaner planet. Int. J. Hydrogen Energy 2005, 30, 795-802. [CrossRef]

9. Holladay, J.D.; Hu, J.; King, D.L.; Wang, Y. An overview of hydrogen production technologies. Catal. Today 2009, 139, 244-260. [CrossRef]

10. Abbasi, M.; Farniaei, M.; Rahimpour, M.R.; Shariati, A. Enhancement of Hydrogen Production and Carbon Dioxide Capturing in a Novel Methane Steam Reformer Coupled with Chemical Looping Combustion and Assisted by Hydrogen Perm-Selective Membranes. Energy Fuels 2013, 27, 5359-5372. [CrossRef]

11. Akbari-Emadabadi, S.; Rahimpour, M.R.; Hafizi, A.; Keshavarz, P. Production of hydrogen-rich syngas using Zr modified Ca-Co bifunctional catalyst-sorbent in chemical looping steam methane reforming. Appl. Energy 2017, 206, 51-62. [CrossRef]

12. Schädel, B.T.; Duisberg, M.; Deutschmann, O. Steam reforming of methane, ethane, propane, butane, and natural gas over a rhodium-based catalyst. Catal. Today 2009, 142, 42-51. [CrossRef]

13. Basagiannis, A.; Verykios, X. Catalytic steam reforming of acetic acid for hydrogen production. Int. J. Hydrogen Energy 2007, 32, 3343-3355. [CrossRef]

14. Armor, J. Catalysis and the hydrogen economy. Catal. Lett. 2005, 101, 131-135. [CrossRef]

15. Chaubey, R.; Sahu, S.; James, O.O.; Maity, S. A review on development of industrial processes and emerging techniques for production of hydrogen from renewable and sustainable sources. Renew. Sustain. Energy Rev. 2013, 23, 443-462. [CrossRef]

16. Forutan, H.; Karimi, E.; Hafizi, A.; Rahimpour, M.R.; Keshavarz, P. Expert representation chemical looping reforming: A comparative study of $\mathrm{Fe}, \mathrm{Mn}, \mathrm{Co}$ and $\mathrm{Cu}$ as oxygen carriers supported on $\mathrm{Al}_{2} \mathrm{O}_{3}$. J. Ind. Eng. Chem. 2015, 21, 900-911. [CrossRef]

17. Rydén, M.; Arjmand, M. Continuous hydrogen production via the steam-iron reaction by chemical looping in a circulating fluidized-bed reactor. Int. J. Hydrogen Energy 2012, 37, 4843-4854. [CrossRef]

18. Zhu, X.; Wei, Y.; Wang, H.; Li, K. Ce-Fe oxygen carriers for chemical-looping steam methane reforming. Int. J. Hydrogen Energy 2013, 38, 4492-4501. [CrossRef]

19. Hafizi, A.; Rahimpour, M.R.; Hassanajili, S. Hydrogen production via chemical looping steam methane reforming process: Effect of cerium and calcium promoters on the performance of $\mathrm{Fe}_{2} \mathrm{O}_{3} / \mathrm{Al}_{2} \mathrm{O}_{3}$ oxygen carrier. Appl. Energy 2016, 165, 685-694. [CrossRef]

20. Moghtaderi, B. Review of the recent chemical looping process developments for novel energy and fuel applications. Energy Fuels 2011, 26, 15-40. [CrossRef]

21. Solunke, R.D.; Veser, G.T. Hydrogen production via chemical looping steam reforming in a periodically operated fixed-bed reactor. Ind. Eng. Chem. Res. 2010, 49, 11037-11044. [CrossRef]

22. Hafizi, A.; Rahimpour, M.R.; Hassanajili, S. High purity hydrogen production via sorption enhanced chemical looping reforming: Application of $22 \mathrm{Fe}_{2} \mathrm{O}_{3} / \mathrm{MgAl}_{2} \mathrm{O}_{4}$ and $22 \mathrm{Fe}_{2} \mathrm{O}_{3} / \mathrm{Al}_{2} \mathrm{O}_{3}$ as oxygen carriers and cerium promoted $\mathrm{CaO}$ as $\mathrm{CO}_{2}$ sorbent. Appl. Energy 2016, 169, 629-641. [CrossRef]

23. Rahimpour, M.R.; Hesami, M.; Saidi, M.; Jahanmiri, A.; Farniaei, M.; Abbasi, M. Methane Steam Reforming Thermally Coupled with Fuel Combustion: Application of Chemical Looping Concept as a Novel Technology. Energy Fuels 2013, 27, 2351-2362. [CrossRef]

24. Alirezaei, I.; Hafizi, A.; Rahimpour, M.R.; Raeissi, S. Application of zirconium modified Cu-based oxygen carrier in chemical looping reforming. J. $\mathrm{CO}_{2}$ Util. 2016, 14, 112-121. [CrossRef]

25. Zafar, Q.; Mattisson, T.; Gevert, B. Redox investigation of some oxides of transition-state metals $\mathrm{Ni}, \mathrm{Cu}, \mathrm{Fe}$, and $\mathrm{Mn}$ supported on $\mathrm{SiO}_{2}$ and $\mathrm{MgAl}_{2} \mathrm{O}_{4}$. Energy Fuels 2006, 20, 34-44. [CrossRef]

26. Adanez, J.; Abad, A.; Garcia-Labiano, F.; Gayan, P.; Luis, F. Progress in chemical-looping combustion and reforming technologies. Prog. Energy Comb. Sci. 2012, 38, 215-282. [CrossRef]

27. Trimm, D.L. Catalysts for the control of coking during steam reforming. Catal. Today 1999, 49, 3-10. [CrossRef] 
28. Van Dillen, A.J.; Terörde, R.J.; Lensveld, D.J.; Geus, J.W.; De Jong, K.P. Synthesis of supported catalysts by impregnation and drying using aqueous chelated metal complexes. J. Catal. 2003, 216, 257-264. [CrossRef]

29. Zhong, X.; Xie, W.; Wang, N.; Duan, Y.; Shang, R.; Huang, L. Dolomite-Derived Ni-Based Catalysts with Fe Modification for Hydrogen Production via Auto-Thermal Reforming of Acetic Acid. Catalysts 2016, 6, 85. [CrossRef]

30. Xu, B.-Q.; Wei, J.-M.; Wang, H.-Y.; Sun, K.-Q.; Zhu, Q.-M. Nano-MgO: Novel preparation and application as support of $\mathrm{Ni}$ catalyst for $\mathrm{CO}_{2}$ reforming of methane. Catal. Today 2001, 68, 217-225. [CrossRef]

31. Kambolis, A.; Matralis, H.; Trovarelli, A.; Papadopoulou, C. Ni/CeO $-\mathrm{ZrO}_{2}$ catalysts for the dry reforming of methane. Appl. Catal. A Gen. 2010, 377, 16-26. [CrossRef]

32. Kim, J.-H.; Suh, D.J.; Park, T.-J.; Kim, K.-L. Effect of metal particle size on coking during $\mathrm{CO}_{2}$ reforming of $\mathrm{CH}_{4}$ over Ni-alumina aerogel catalysts. Appl. Catal. A Gen. 2000, 197, 191-200. [CrossRef]

33. Bengaard, H.S.; Nørskov, J.K.; Sehested, J.; Clausen, B.; Nielsen, L.; Molenbroek, A.; Rostrup-Nielsen, J. Steam reforming and graphite formation on Ni catalysts. J. Catal. 2002, 209, 365-384. [CrossRef]

34. Bradford, M.; Vannice, M. $\mathrm{CO}_{2}$ reforming of $\mathrm{CH}_{4}$. Catal. Rev. 1999, 41, 1-42. [CrossRef]

35. Takahashi, R.; Sato, S.; Sodesawa, T.; Tomiyama, S. $\mathrm{CO}_{2}$-reforming of methane over $\mathrm{Ni} / \mathrm{SiO}_{2}$ catalyst prepared by homogeneous precipitation in sol-gel-derived silica gel. Appl. Catal. A Gen. 2005, 286, 142-147. [CrossRef]

36. Zhang, M.; Ji, S.; Hu, L.; Yin, F.; Li, C.; Liu, H. Structural characterization of highly stable Ni/SBA-15 catalyst and its catalytic performance for methane reforming with $\mathrm{CO}_{2}$. Chin. J. Catal. 2006, 27, 777-781. [CrossRef]

37. Liu, D.; Quek, X.Y.; Cheo, W.N.E.; Lau, R.; Borgna, A.; Yang, Y. MCM-41 supported nickel-based bimetallic catalysts with superior stability during carbon dioxide reforming of methane: Effect of strong metal-support interaction. J. Catal. 2009, 266, 380-390. [CrossRef]

38. Liu, Z.; Zhou, J.; Cao, K.; Yang, W.; Gao, H.; Wang, Y.; Li, H. Highly dispersed nickel loaded on mesoporous silica: One-spot synthesis strategy and high performance as catalysts for methane reforming with carbon dioxide. Appl. Catal. B Environ. 2012, 125, 324-330. [CrossRef]

39. Li, L.; He, S.; Song, Y.; Zhao, J.; Ji, W.; Au, C.-T. Fine-tunable Ni@ porous silica core-shell nanocatalysts: Synthesis, characterization, and catalytic properties in partial oxidation of methane to syngas. J. Catal. 2012, 288, 54-64. [CrossRef]

40. Carrero, A.; Calles, J.; Vizcaíno, A. Hydrogen production by ethanol steam reforming over Cu-Ni/SBA-15 supported catalysts prepared by direct synthesis and impregnation. Appl. Catal. A Gen. 2007, 327, 82-94. [CrossRef]

41. Klimova, T.; Calderón, M.; Ramírez, J. Ni and Mo interaction with Al-containing MCM-41 support and its effect on the catalytic behavior in DBT hydrodesulfurization. Appl. Catal. A Gen. 2003, 240, 29-40. [CrossRef]

42. Zhang, S.; Muratsugu, S.; Ishiguro, N.; Tada, M. Ceria-doped Ni/SBA-16 catalysts for dry reforming of methane. ACS Catal. 2013, 3, 1855-1864. [CrossRef]

43. Kantorovich, D.; Haviv, L.; Vradman, L.; Landau, M. Behaviour of NiO and NiO pohases at high loadings, in SBA-15 and SBA-16 mesoporous silica matrices. Stud. Surf. Sci. Catal. 2005, 156, 147-154. [CrossRef]

44. Luna, A.E.C.; Iriarte, M.E. Carbon dioxide reforming of methane over a metal modified $\mathrm{Ni}^{-} \mathrm{Al}_{2} \mathrm{O}_{3}$ catalyst. Appl. Catal. A Gen. 2008, 343, 10-15. [CrossRef]

45. Hu, Y.H.; Ruckenstein, E. The characterization of a highly effective $\mathrm{NiO} / \mathrm{MgO}$ solid solution catalyst in the $\mathrm{CO}_{2}$ reforming of $\mathrm{CH}_{4}$. Catal. Lett. 1997, 43, 71-77. [CrossRef]

46. $\mathrm{Li}, \mathrm{B} . ; \mathrm{Xu}, \mathrm{X}$.; Zhang, S. Synthesis gas production in the combined $\mathrm{CO}_{2}$ reforming with partial oxidation of methane over Ce-promoted $\mathrm{Ni} / \mathrm{SiO}_{2}$ catalysts. Int. J. Hydrogen Energy 2013, 38, 890-900. [CrossRef]

47. Qian, L.; Ma, Z.; Ren, Y.; Shi, H.; Yue, B.; Feng, S.; Shen, J.; Xie, S. Investigation of La promotion mechanism on Ni/SBA-15 catalysts in $\mathrm{CH}_{4}$ reforming with $\mathrm{CO}_{2}$. Fuel 2014, 122, 47-53. [CrossRef]

48. Meshksar, M.; Daneshmand-Jahromi, S.; Rahimpour, M.R. Synthesis and characterization of cerium promoted $\mathrm{Ni} / \mathrm{SBA}-16$ oxygen carrier in cyclic chemical looping steam methane reforming. J. Taiwan Inst. Chem. Eng. 2017, 76, 73-82. [CrossRef]

49. Shi, C.; Zhang, P. Effect of a second metal (Y, K, Ca, Mn or Cu) addition on the carbon dioxide reforming of methane over nanostructured palladium catalysts. Appl. Catal. B Environ. 2012, 115, 190-200. [CrossRef]

50. Li, J.; Xia, C.; Au, C.; Liu, B. $\mathrm{Y}_{2} \mathrm{O}_{3}$-promoted NiO/SBA-15 catalysts highly active for $\mathrm{CO}_{2} / \mathrm{CH}_{4}$ reforming. Int. J. Hydrogen Energy 2014, 39, 10927-10940. [CrossRef] 
51. Yogamalar, R.; Srinivasan, R.; Vinu, A.; Ariga, K.; Bose, A.C. X-ray peak broadening analysis in ZnO nanoparticles. Solid State Commun. 2009, 149, 1919-1923. [CrossRef]

52. Kaneko, K. Determination of pore size and pore size distribution. J. Membr. Sci. 1994, 96, 59-89. [CrossRef]

53. Cohan, L.H. Hysteresis and the Capillary Theory of Adsorption of Vapors1. J. Am. Chem. Soc. 1944, 66, 98-105. [CrossRef]

54. Tsoncheva, T.; Linden, M.; Areva, S.; Minchev, C. Copper oxide modified large pore ordered mesoporous silicas for ethyl acetate combustion. Catal. Commun. 2006, 7, 357-361. [CrossRef]

55. Rodrıguez-Castellón, E.; Dıaz, L.; Braos-Garcı, P.; Mérida-Robles, J.; Maireles-Torres, P.; Jiménez-López, A.; Vaccari, A. Nickel-impregnated zirconium-doped mesoporous molecular sieves as catalysts for the hydrogenation and ring-opening of tetralin. Appl. Catal. A Gen. 2003, 240, 83-94. [CrossRef]

56. Yamazaki, T.; Kikuchi, N.; Katoh, M.; Hirose, T.; Saito, H.; Yoshikawa, T.; Wada, M. Behavior of steam reforming reaction for bio-ethanol over $\mathrm{Pt} / \mathrm{ZrO}_{2}$ catalysts. Appl. Catal. B Environ. 2010, 99, 81-88. [CrossRef]

57. Profeti, L.P.; Dias, J.A.; Assaf, J.M.; Assaf, E.M. Hydrogen production by steam reforming of ethanol over Ni-based catalysts promoted with noble metals. J. Power Sources 2009, 190, 525-533. [CrossRef]

58. De Diego, LF.; Ortiz, M.; García-Labiano, F.; Adánez, J.; Abad, A.; Gayán, P. Synthesis gas generation by chemical-looping reforming using a Nibased oxygen carrier. Energy Procedia 2009, 1, 3-10. [CrossRef]

59. Akbari-Emadabadi, S.; Rahimpour, M.R.; Hafizi, A.; Keshavarz, P. Promotion of Ca-Co bifunctional catalyst/sorbent with yttrium for hydrogen production in modified chemical looping steam methane reforming. Catalysts 2017, 7, 270. [CrossRef]

60. Antzara, A.; Heracleous, E.; Bukur, D.B.; Lemonidou, A.A. Thermodynamic analysis of hydrogen production via chemical looping steam methane reforming coupled with in situ $\mathrm{CO}_{2}$ capture. Int. J. Greenh. Gas Control 2015, 32, 115-128. [CrossRef]

61. Adiya, Z.I.; Dupont, V.; Mahmud, T. Chemical equilibrium analysis of hydrogen production from shale gas using sorption enhanced chemical looping steam reforming. Fuel Process. Technol. 2017, 159, 128-144. [CrossRef]

62. Silva, J.M.; Soria, M.A.; Madeira, L.M. Thermodynamic analysis of Glycerol Steam Reforming for hydrogen production with in situ hydrogen and carbon dioxide separation. J. Power Sources 2015, 273, 423-430. [CrossRef]

63. He, H.; Dai, H.; Wong, K.W.; Au, C. $\mathrm{RE}_{0.6} \mathrm{Zr}_{0.4-\mathrm{x}} \mathrm{Y}_{\mathrm{x}} \mathrm{O}_{2}(\mathrm{RE}=\mathrm{Ce}, \mathrm{Pr} ; \mathrm{x}=0$, 0.05) solid solutions: An investigation on defective structure, oxygen mobility, oxygen storage capacity, and redox properties. Appl. Catal. A Gen. 2003, 251, 61-74. [CrossRef]

64. Oemar, U.; Hidajat, K.; Kawi, S. Role of catalyst support over PdO-NiO catalysts on catalyst activity and stability for oxy-CO $\mathrm{CO}_{2}$ reforming of methane. Appl. Catal. A Gen. 2011, 402, 176-187. [CrossRef]

65. Belhadi, A.; Trari, M.; Rabia, C.; Cherifi, O. Methane steam reforming on supported nickel based catalysts. effect of oxide $\mathrm{ZrO}_{2}, \mathrm{La}_{2} \mathrm{O}_{3}$ and nickel composition. Open J. Phys. Chem. 2013, 3, 89-96. [CrossRef]

66. Wan, H.; Li, X.; Ji, S.; Huang, B.; Wang, K.; Li, C. Effect of Ni loading and $\mathrm{Ce}_{x} \mathrm{Zr}_{\mathrm{i}-\mathrm{x}} \mathrm{O}_{2}$ promoter on Ni-based SBA-15 catalysts for steam reforming of methane. J. Nat. Gas Chem. 2007, 16, 139-147. [CrossRef]

67. Rakass, S.; Oudghiri-Hassani, H.; Rowntree, P.; Abatzoglou, N. Steam reforming of methane over unsupported nickel catalysts. J. Power Sources 2006, 158, 485-496. [CrossRef]

(C) 2017 by the authors. Licensee MDPI, Basel, Switzerland. This article is an open access article distributed under the terms and conditions of the Creative Commons Attribution (CC BY) license (http://creativecommons.org/licenses/by/4.0/). 